\title{
Adrenocortical zonation, renewal, and remodeling
}

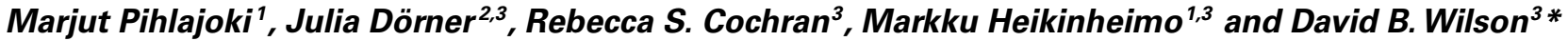 \\ 1 Helsinki University Central Hospital, Children's Hospital, University of Helsinki, Helsinki, Finland \\ ${ }^{2}$ Hochschule Mannheim - University of Applied Sciences, Mannheim, Germany \\ ${ }^{3}$ St. Louis Children's Hospital, Washington University School of Medicine, St. Louis, MO, USA
}

Edited by:

Pierre Val, Centre National de la Recherche Scientifique, France

Reviewed by:

David Breault, Boston Children's Hospital, USA

Gary Hammer, University of

Michigan, USA

${ }^{*}$ Correspondence:

David B. Wilson, Washington

University School of Medicine, Box 8208, 660 South Euclid Avenue,

St. Louis, MO 63110, USA

e-mail:wilson_d@wustl.edu
The adrenal cortex is divided into concentric zones. In humans the major cortical zones are the zona glomerulosa, zona fasciculata, and zona reticularis. The adrenal cortex is a dynamic organ in which senescent cells are replaced by newly differentiated ones. This constant renewal facilitates organ remodeling in response to physiological demand for steroids. Cortical zones can reversibly expand, contract, or alter their biochemical profiles to accommodate needs. Pools of stem/progenitor cells in the adrenal capsule, subcapsular region, and juxtamedullary region can differentiate to repopulate or expand zones. Some of these pools appear to be activated only during specific developmental windows or in response to extreme physiological demand. Senescent cells can also be replenished through direct lineage conversion; for example, cells in the zona glomerulosa can transform into cells of the zona fasciculata. Adrenocortical cell differentiation, renewal, and function are regulated by a variety of endocrine/paracrine factors including adrenocorticotropin, angiotensin II, insulin-related growth hormones, luteinizing hormone, activin, and inhibin. Additionally, zonation and regeneration of the adrenal cortex are controlled by developmental signaling pathways, such as the sonic hedgehog, delta-like homolog 1, fibroblast growth factor, and WNT/ $\beta$-catenin pathways. The mechanisms involved in adrenocortical remodeling are complex and redundant so as to fulfill the offsetting goals of organ homeostasis and stress adaptation.

Keywords: adrenal cortex, hormone, plasticity, stem cell, steroid, steroidogenesis

\section{INTRODUCTION}

The adrenal cortex is a major source of steroid hormones, which are synthesized from cholesterol through the sequential actions of a series of cytochrome P450 (CYP) enzymes and hydroxysteroid dehydrogenases (HSDs) (Figure 1) (1). Anatomically and functionally distinct zones in the adrenal cortex synthesize specific steroid hormones in response to endocrine and paracrine signals. The regulation of adrenocortical development and homeostasis has been the subject of intensive investigation over the past decade (2-4). This review article summarizes recent advances in our understanding of adrenocortical zonation, renewal, and remodeling. Animal models useful for studies of adrenocortical biology, such as the mouse, rat, and ferret, are highlighted.

\section{ADRENOCORTICAL ZONATION IN HUMANS AND ANIMAL MODELS}

The adrenal cortex of humans is composed of three concentric layers: the zona glomerulosa $(\mathrm{zG})$, zona fasciculata $(\mathrm{zF})$, and zona reticularis (zR) [reviewed in Ref. (2)]. The outermost layer, the $\mathrm{zG}$, functions as part of the renin-angiotensin-aldosterone system (RAAS). In response to angiotensin II (Ang II) or elevated plasma potassium ion $\left(\mathrm{K}^{+}\right)$concentrations, $\mathrm{zG}$ cells secrete aldosterone, a mineralocorticoid that induces the retention of sodium ion $\left(\mathrm{Na}^{+}\right)$and water and the excretion of $\mathrm{K}^{+}$by the kidney. Cells in the $\mathrm{zG}$ express the Ang II receptor (AT1R) and aldosterone synthase (CYP11B2). At the ultrastructural level, $\mathrm{zG}$ cells are typified by numerous mitochondria with lamelliform cristae and a few cytoplasmic lipid droplets (Figure 2A). Cells in the zF produce glucocorticoids as part of the hypothalamic-pituitary-adrenal (HPA) axis. zF cells respond to adrenocorticotropic hormone (ACTH) via its receptor (MC2R) and the accessory protein MRAP. Cells in the $\mathrm{zF}$ are organized in cord-like structures, or fascicles, that are surrounded by fenestrated capillaries. Cells in this zone contain numerous mitochondria with tubulovesicular cristae, many cytoplasmic lipid droplets, and prominent smooth endoplasmic reticulum (Figure 2B) $(5,6)$. The innermost layer of the cortex, the $\mathrm{zR}$, secretes the weak androgen dehydroepiandrosterone (DHEA) and its sulfated form DHEA-S (1). Cells of the zR resemble those of the $\mathrm{zF}$ but contain fewer lipid droplets and more lysosomes and vacuoles (6). The adrenal gland is covered by a fibrous capsule that serves as both a support structure and a reservoir of stem/progenitor cells for the cortex (see Section "Adrenocortical Stem Cells") (7).

Species differ in their adrenocortical zonation patterns (8) (Figure 3). In the mouse and rat, the adrenal cortex contains $\mathrm{zG}$ and $\mathrm{zF}$, but there is no recognizable $\mathrm{zR}$. The adrenal cortex of the young mouse contains an additional, ephemeral layer known as the $\mathrm{X}$-zone $(9,10)$. The function of the $\mathrm{X}$-zone remains controversial, but it may be involved in progesterone catabolism (11). The rat adrenal cortex contains a less prominent layer, the undifferentiated zone $(\mathrm{zU})$, located between the $\mathrm{zG}$ and $\mathrm{zF}(12)$. The $\mathrm{zU}$ has been implicated in adrenocortical homeostasis and remodeling (see Section "Delta-like Homologue 1 Pathway") $(12,13)$. Cells in the inner aspect of the $\mathrm{zU}$ express $\mathrm{MC} 2 \mathrm{R}$ and cholesterol side-chain 


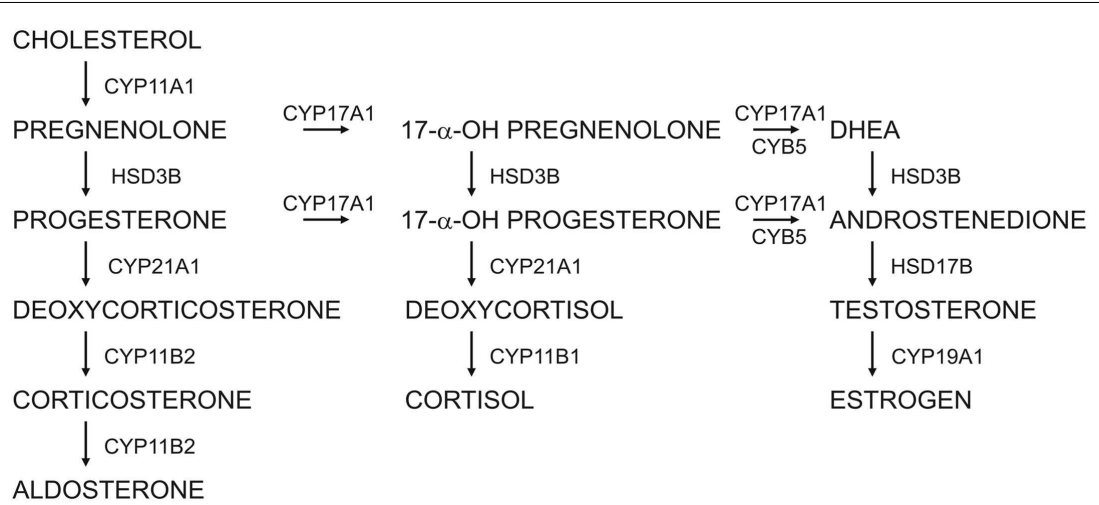

FIGURE 1 | Steroidogenic pathways in the human adrenal cortex and gonads

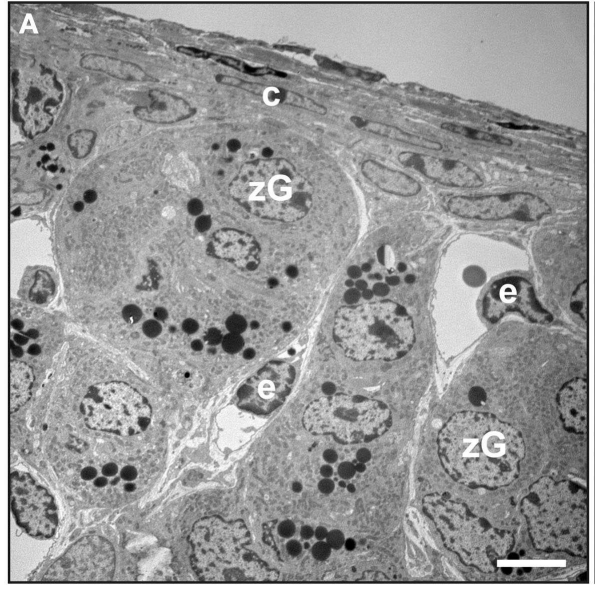

FIGURE 2 | Electron microscopy of mouse adrenal cortex. Adrenal glands from a 4-month-old female mouse were fixed in Karnovsky's solution, postfixed in $2 \% \mathrm{OsO}_{4}$, dehydrated, and then embedded in epon. Thin sections were stained with uranyl acetate plus lead citrate and

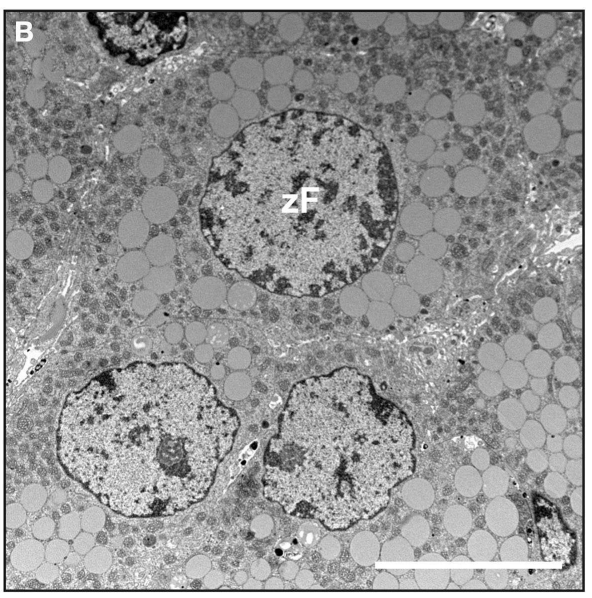

examined by transmission electron microscopy. (A) Adrenal capsule and zona glomerulosa. (B) Zona fasciculata. Abbreviations: c, capsule; e, endothelial cell; zF, zona fasciculata cell; zG, zona glomerulosa cell. Bars, $4 \mu \mathrm{m}$. cleavage enzyme (CYP11A1), which catalyzes the first reaction in steroidogenesis. The inner $\mathrm{zU}$ lacks expression of markers of the zG (Cyp11b2) or zF (steroid 11ß-hydroxylase; Cyp11b1) (14). Thus, the inner $\mathrm{zU}$ may represent a transitional population of cells committed to the steroidogenic phenotype. An analogous layer, the zona intermedia (zI), is present in the adrenal glands of ferrets (15). Recently, the spiny mouse (genus Acomys) has attracted attention as a novel model for the study of adrenocortical development and function. In contrast to the laboratory mouse (genus $M u s$ ), the adrenal cortex of the spiny mouse contains the $\mathrm{zR}$ and secretes both cortisol and DHEA (16). In this respect the adrenal gland of the spiny mouse mimics that of humans.

Species also vary in the repertoire of steroidogenic enzymes and cofactors expressed in the adrenal cortex, and these differences impact function (Figure 3). Two factors that are differentially expressed among species are $17 \alpha$-hydroxylase/17,20 lyase (CYP17A1) and cytochrome $b_{5}\left(\mathrm{CYB}_{5}\right)$. CYP17A1, a bifunctional enzyme, catalyzes the $17 \alpha$-hydroxylation reaction required for cortisol synthesis and the 17,20-lyase reaction required for the androgen production (1). The lyase activity is enhanced by allosteric interactions with $\mathrm{CYB}_{5}$ (1). Cells in the $\mathrm{zF}$ and $\mathrm{zR}$ of humans and ferrets have $17 \alpha$-hydroxylase activity, so cortisol is the principal glucocorticoid secreted by the adrenal gland of these organisms (8). In humans the adrenal cortex begins to produce DHEA and DHEA-S at adrenarche, contemporaneous with increased expression of CYB5 in the $\mathrm{zR}(1)$. The adrenal glands of ferrets produce only limited amounts of androgens due to low $\mathrm{CYB}_{5}$ expression $(8,17)$. Cells in the adrenal cortex of adult mice and rats lack CYP17A1, so corticosterone is the principal glucocorticoid secreted, and adrenal androgens are not produced (8). The relative strengths and weaknesses of established and emerging animal models are summarized in Table 1.

\section{ADRENOCORTICAL RENEWAL AND REMODELING}

The adult adrenal cortex is a dynamic tissue. Cells lost through senescence or injury are continually replenished through cell 


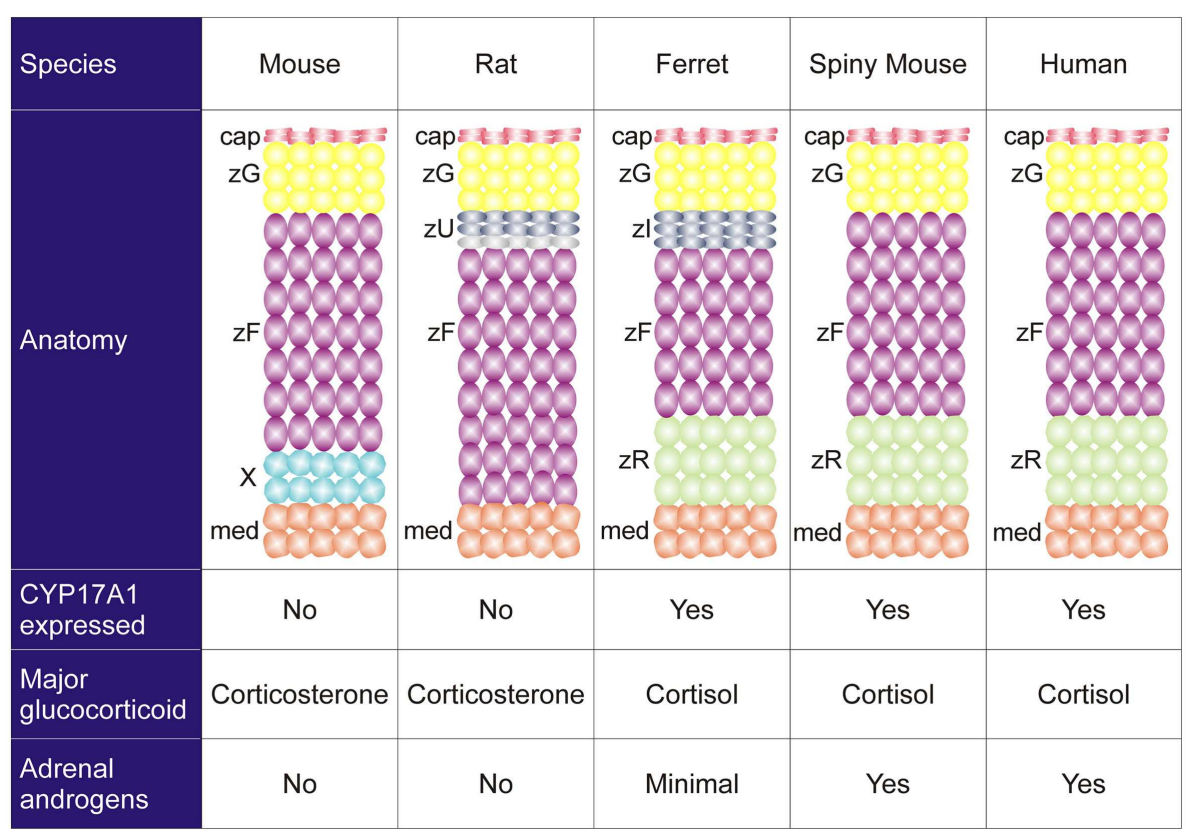

FIGURE 3 | Comparative anatomy and physiology of the adrenal cortex. The undifferentiated zone of the rat adrenal is subdivided into outer (dark gray) and inner (light gray) zones that differ in marker expression and function (see the text). Abbreviations: cap, capsule; med, medulla; $X, X$-zone; $z F$, zona fasciculata; $z G$, zona glomerulosa; $z l$, zona intermedia; $z R$, zona reticularis; $z U$, undifferentiated zone.

Table 1 |Advantages and disadvantages of various animal models for studies of adrenocortical zonation and remodeling

\begin{tabular}{|c|c|c|c|c|}
\hline & Mouse & Rat & Spiny mouse & Ferret \\
\hline Advantages & $\begin{array}{l}\text { - Genetically and epigenetically } \\
\text { tractable } \\
\text { - Well suited for transplantation } \\
\text { experiments } \\
\text { - Gonadectomy triggers the } \\
\text { accumulation of gonadal-like } \\
\text { cells in the adrenal cortex (see } \\
\text { Section "LH Signaling") }\end{array}$ & $\begin{array}{l}\text { - Well suited for } \\
\text { pharmacological studies (see } \\
\text { Section "Adrenocortical } \\
\text { Renewal and Remodeling") } \\
\text { - Adrenal enucleation } \\
\text { experiments are feasible (see } \\
\text { Section "Adrenocortical } \\
\text { Renewal and Remodeling") }\end{array}$ & $\begin{array}{l}\text { - Adrenal gland is } \\
\text { anatomically and } \\
\text { functionally similar to that } \\
\text { of humans }\end{array}$ & $\begin{array}{l}\text { - Well characterized } \\
\text { neuroendocrine physiology } \\
\text { - Gonadectomy triggers the } \\
\text { accumulation of } \\
\text { gonadal-like cells in the } \\
\text { adrenal cortex (see Section } \\
\text { "LH Signaling") }\end{array}$ \\
\hline Disadvantages & $\begin{array}{l}\text { - Lacks zR and does not } \\
\text { produce androgens }\end{array}$ & $\begin{array}{l}\text { - Lacks zR and does not } \\
\text { produce androgens }\end{array}$ & $\begin{array}{l}\text { - Not widely available } \\
\text { - Not standardized with } \\
\text { regard to genotype }\end{array}$ & $\begin{array}{l}\text { - Not standardized with } \\
\text { regard to genotype }\end{array}$ \\
\hline
\end{tabular}

division and differentiation $(2,4)$. In the adult adrenal gland, most cell proliferation occurs near the periphery of the cortex, as shown by bromodeoxyuridine and $\left[{ }^{3} \mathrm{H}\right]$ thymidine labeling experiments [reviewed in Ref. (3)]. The remarkable regenerative capacity of the organ is evidenced by rat adrenal enucleation experiments, wherein the gland is incised and squeezed so as to extrude the cortex. Within weeks a new adrenal cortex regenerates from the remaining capsule and adherent subcapsular cells [reviewed in Ref. (18)].

Constant cellular turnover in the adrenal cortex facilitates rapid organ remodeling in response to physiological demand for steroids. Zones can reversibly enlarge, shrink, or alter their biochemical profiles to accommodate physiological needs or in response to experimental manipulations (Table 2). For example, administration of captopril, an inhibitor of the RAAS, leads to contraction of the $\mathrm{zG}$ in rats [reviewed in Ref. (2)].

\section{OVERVIEW OF ADRENOCORTICAL DEVELOPMENT}

Embryogenesis and early postnatal development provide a contextual framework for understanding the mechanisms involved in adrenocortical zonation and homeostasis. Although structurally and functionally distinct, the adrenal cortex, ovary, and testis arise from a common progenitor, the adrenocortical primordium (AGP). The AGP is derived from a specialized region 
Table 2 | Triggers of zonal remodeling in the adrenal cortex

\begin{tabular}{|c|c|c|c|}
\hline Zone (species) & $\begin{array}{l}\text { Physiological or } \\
\text { experimental } \\
\text { trigger }\end{array}$ & Effect & Reference \\
\hline \multirow[t]{2}{*}{ zG (rat) } & $\begin{array}{l}\downarrow\left[\mathrm{Na}^{+}\right] \text {or } \uparrow\left[\mathrm{K}^{+}\right] \\
\text {in diet }\end{array}$ & $\begin{array}{l}\text { Expands the zone, } \\
\text { increasing aldosterone } \\
\text { production }\end{array}$ & $(2)$ \\
\hline & $\begin{array}{l}\uparrow\left[\mathrm{Na}^{+}\right] \text {or } \downarrow\left[\mathrm{K}^{+}\right] \\
\text {in diet }\end{array}$ & $\begin{array}{l}\text { Contracts the zone, } \\
\text { decreasing aldosterone } \\
\text { production }\end{array}$ & \\
\hline \multirow[t]{2}{*}{ zF (rat) } & АCTH & $\begin{array}{l}\text { Expands the zone, } \\
\text { increasing } \\
\text { glucocorticoid } \\
\text { production }\end{array}$ & $(2)$ \\
\hline & Dexamethasone & $\begin{array}{l}\text { Contracts the zone, } \\
\text { decreasing } \\
\text { glucocorticoid } \\
\text { production }\end{array}$ & \\
\hline \multirow[t]{3}{*}{ zR (primates) } & $\begin{array}{l}\text { Adrenarche in } \\
\text { humans and } \\
\text { chimpanzees }\end{array}$ & $\begin{array}{l}\text { Increases the } \\
\text { expression of } \mathrm{CYB}_{5} \text {, } \\
\text { enhancing DHEA } \\
\text { production }\end{array}$ & (19) \\
\hline & $\begin{array}{l}\text { Social status in } \\
\text { marmosets }\end{array}$ & $\begin{array}{l}\text { Adult females develop } \\
\text { a functional } z R \text { in a } \\
\text { reversible manner } \\
\text { dependent on social } \\
\text { status }\end{array}$ & $(20)$ \\
\hline & $\begin{array}{l}\text { Cortisol in human } \\
\text { adrenocortical } \\
\text { cells }\end{array}$ & $\begin{array}{l}\text { Stimulates DHEA } \\
\text { production through } \\
\text { competitive inhibition } \\
\text { of } 3 \beta \mathrm{HSD} 2 \text { activity }\end{array}$ & $(21)$ \\
\hline \multirow[t]{3}{*}{ X-zone (mouse) } & $\begin{array}{l}\text { Puberty in males } \\
\text { or first pregnancy } \\
\text { in females }\end{array}$ & $\begin{array}{l}\text { Induces regression of } \\
\text { the zone }\end{array}$ & $(22)$ \\
\hline & Activin & $\begin{array}{l}\text { Induces regression of } \\
\text { the zone }\end{array}$ & (23) \\
\hline & Gonadectomy & $\begin{array}{l}\text { Delays regression of } \\
\text { the zone or induces } \\
\text { growth of a secondary } \\
\text { zone }\end{array}$ & $(22,23)$ \\
\hline
\end{tabular}

of celomic epithelium known as the urogenital ridge (Figure 4), which also gives rise to the kidney and progenitors of definitive hematopoiesis. Cells in the AGP co-express the transcription factor genes Wilms tumor suppressor-1 (Wt1), GATA-binding protein 4 (Gata4), and steroidogenic factor-1 ( $S f 1$, also called AdBP4 or Nr5a1) [reviewed in Ref. $(2,24,25)]$. As development proceeds, progenitors of the adrenal cortex and the gonad separate and activate different transcriptional programs. Adrenal progenitor cells in the AGP migrate dorsomedially into subjacent mesenchyme, upregulate expression of $S f 1$, and downregulate expression of Wt1 and Gata4 $(25,26)$. In contrast, gonadal progenitor cells in the

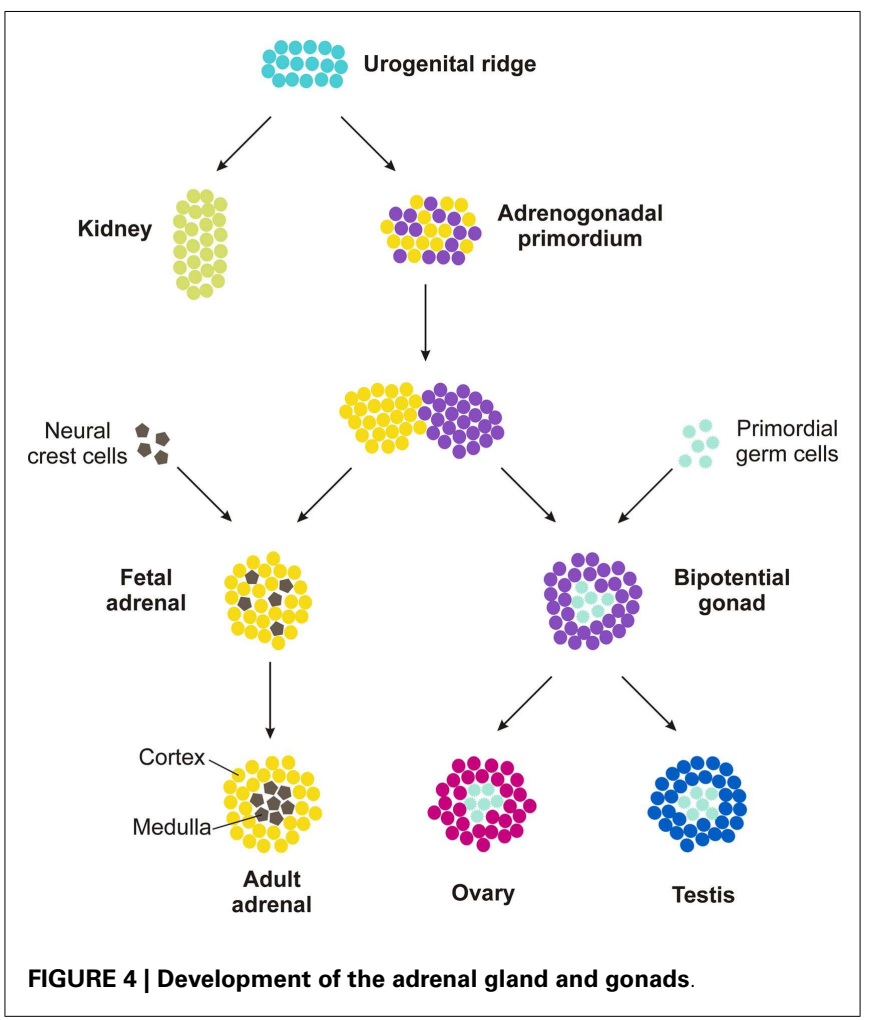

AGP migrate dorsolaterally and maintain expression of Sf1, Wt1, and Gata4. Adrenal precursors combine with neural-crest derived sympathoblasts, the precursors of chromaffin cells in the medulla, to form the adrenal anlagen. Gonadal progenitors combine with primordial germ cells to form the bipotential gonad. Subsequently, the nascent adrenal glands become enveloped by capsule cells, which are derived from both surrounding mesenchyme and fetal adrenal cells that previously expressed $S f 1$ [reviewed in Ref. (27)].

In rodents, zonal patterns of steroidogenic enzyme expression first become evident during embryonic development [reviewed in Ref. (24)]. In mice, expression of Cyp11a1 is first detectable in the nascent adrenal at embryonic day (E) 11.5-12.5 $(26,28)$, and there is a concurrent increase in the level of endogenous biotin (29). Expression of the zF marker Cyp11b1 begins at E13.5, whereas expression of the zG markers Ang II receptor type 1 (At1b) and $C y p 11 b 2$ appears in the periphery of the cortex just before birth, and $C y p 11 b 2$ and $C y p 11 b 1$ expression domains are mutually exclusive at this stage (30-32).

By the eighth week of gestation in humans, the fetal adrenal cortex contains two morphologically distinct layers: an inner fetal zone (Fz) and an outer definitive zone (Dz) (33). The Fz is thick and contains large, eosinophilic cells, whereas the $\mathrm{Dz}$ is thin and contains small, basophilic cells. Functionally, the Fz resembles the adult zR. The $\mathrm{Fz}$ expresses CYP17A1 and CYB5 and produces large amounts of DHEA and DHEA-S, which are converted by the sequential actions of the liver and placenta into estrogens. A third cortical zone, termed the transitional zone $(\mathrm{Tz})$, becomes evident shortly thereafter. The Tz produces cortisol, and an early burst of cortisol production during the ninth week of gestation, coinciding with a transient increase in expression of $3 \beta$-hydroxysteroid 
dehydrogenase type 2 (HSD3B2), is thought to safeguard female sexual development by suppressing the fetal HPA axis and thereby inhibiting adrenal androgen production (34). At birth, the adrenal gland is almost as large as the kidney, but the size of the organ decreases dramatically over first 2 weeks of neonatal life; the Fz involutes via apoptosis, and there is a concomitant reduction in adrenal androgen production (1). The mouse X-zone, a remnant of the fetal adrenal that regresses postnatally (9), is thought to be the analog of the human Fz. Postnatally, the human Dz differentiates into the anatomically and functionally distinct zones of the adult cortex.

\section{ADRENOCORTICAL STEM CELLS}

The adrenal cortex contains stem/progenitor cells that can divide and differentiate to replenish senescing cells and maintain or expand zones (Table 3) [reviewed in Ref. (4)]. In one longstanding model of adrenal zonation, the cell migration model, stem/progenitor cells in the periphery of the adrenal cortex differentiate and migrate centripetally to repopulate the gland before undergoing apoptosis in the juxtamedullary region (35). Aspects of this model have been validated through lineage tracing analyses $(24,30,36)$, but recent studies indicate that the regulation of zonation is more complex than originally appreciated [reviewed in Ref. (13)]. It is now clear that distinct pools of stem/progenitor cells exist in the adrenal capsule, subjacent cortex, juxtamedullary region, and other sites (Table 3). Some of these pools appear to be activated only during specific developmental windows or in response to extreme physiological demand. Under certain experimental conditions, adrenocortical zones can be replenished by centrifugal migration $(37,38)$. For example, stem/progenitor cells in the juxtamedullary region can proliferate, differentiate, and centrifugally repopulate the cortex with fetal-like cells, as is seen in gonadectomy (GDX)-induced secondary X-zone formation and in a genetic model of dysregulated cAMP production $(37,39,40)$. The mechanisms that govern centripetal and centrifugal migration are not well understood.
Whether centrifugal migration operates under basal conditions is unknown.

\section{ADRENOCORTICAL CELL PLASTICITY}

Cell plasticity is another mechanism for replenishing adrenocortical cells lost to senescence or injury. Plasticity refers to the ability of cells to adopt an alternate functional identity in response to cues from the hormonal milieu and cellular microenvironment. One form of plasticity entails trans-differentiation, the direct conversion of one differentiated cell into a differentiated cell of another lineage (42). A second form of plasticity involves de-differentiation, wherein a differentiated cell reverts to a less differentiated cell within the same tissue lineage (42). Interconversion of differentiated cells, either through trans- or de-differentiation, provides an alternative to regeneration via mobilization of stem/progenitor cells. Such functional redundancy ensures organ homeostasis and an optimal adaptation to stress (13).

The plasticity of differentiated adrenocortical cells was elegantly demonstrated in fate mapping studies by Freedman et al. (36), who used Cyp11b2-Cre to permanently mark zG cells and their descendants with green fluorescent protein (GFP). By tracing the fate of $\mathrm{GFP}^{+}$cells, the investigators showed that adrenocortical zonation is orchestrated in part by direct lineage conversion of $z G$ cells into zF cells (Figure 5). To show that zG-to-zF conversion participates in adrenocortical remodeling, Freedman et al. treated adult mice with glucocorticoids to inhibit the HPA axis (36). Glucocorticoid treatment caused contraction of the $\mathrm{zF}$ and loss of $\mathrm{GFP}^{+}$cells in this zone. Following withdrawal of exogenous glucocorticoids, $z \mathrm{G}-$ to-zF conversion resumed and the $\mathrm{zF}$ expanded. Remarkably, when conversion of $z G$ to $z F$ cells was abrogated through conditional deletion of the $S f 1$ gene in CYP11B2 ${ }^{+}$ cells, a functional $\mathrm{zF}$ still formed, implying the existence of alternate routes for differentiation of $\mathrm{zF}$ cells. These alternative sources for $\mathrm{zF}$ cells remain the subject of active investigation. Collectively, these results support a model in which differentiated cells undergo lineage conversion during adrenocortical renewal and remodeling.

Table 3 | Stem/progenitor cell populations that give rise to steroidogenic and non-steroidogenic cells in the adrenal cortex

\begin{tabular}{|c|c|c|c|}
\hline $\begin{array}{l}\text { Stem/progenitor } \\
\text { population }\end{array}$ & Location & Comments & Reference \\
\hline WT1+ progenitors & Capsule & $\begin{array}{l}\text { Under basal conditions, WT1+ capsule cells give rise to steroidogenic cells in the } \\
\text { adrenal cortex. GDX triggers their differentiation into gonadal-like tissue }\end{array}$ & $(25)$ \\
\hline GLI1+ progenitors & Capsule & $\begin{array}{l}\text { In response to SHH, GLI1+ progenitors migrate into the cortex and differentiate into } \\
\text { steroidogenic cells }\end{array}$ & $(27,30,41)$ \\
\hline $\mathrm{TCF} 21^{+}$progenitors & Capsule & $\mathrm{TCF}_{21}{ }^{+}$capsular cells give rise to non-steroidogenic stromal cells in the adrenal cortex & $(27)$ \\
\hline $\mathrm{SHH}^{+}$progenitors & Subcapsular region & These progenitors give rise to steroidogenic cells in the $z F$ and $z G$ but not capsule cells & $(27,30,41)$ \\
\hline $\begin{array}{l}\text { Fetal adrenal-like } \\
\text { progenitors }\end{array}$ & Juxtamedullary region & $\begin{array}{l}\text { These progenitors, normally dormant in the adult, can become activated following } \\
\text { certain experimental manipulations and migrate centrifugally }\end{array}$ & $(37,39,40)$ \\
\hline
\end{tabular}

These progenitor populations, defined by fate mapping studies and related techniques, are not mutually exclusive. For example, WT1 ${ }^{+}$progenitors have been shown

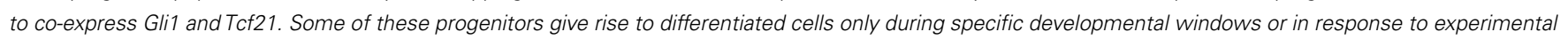
manipulation. 


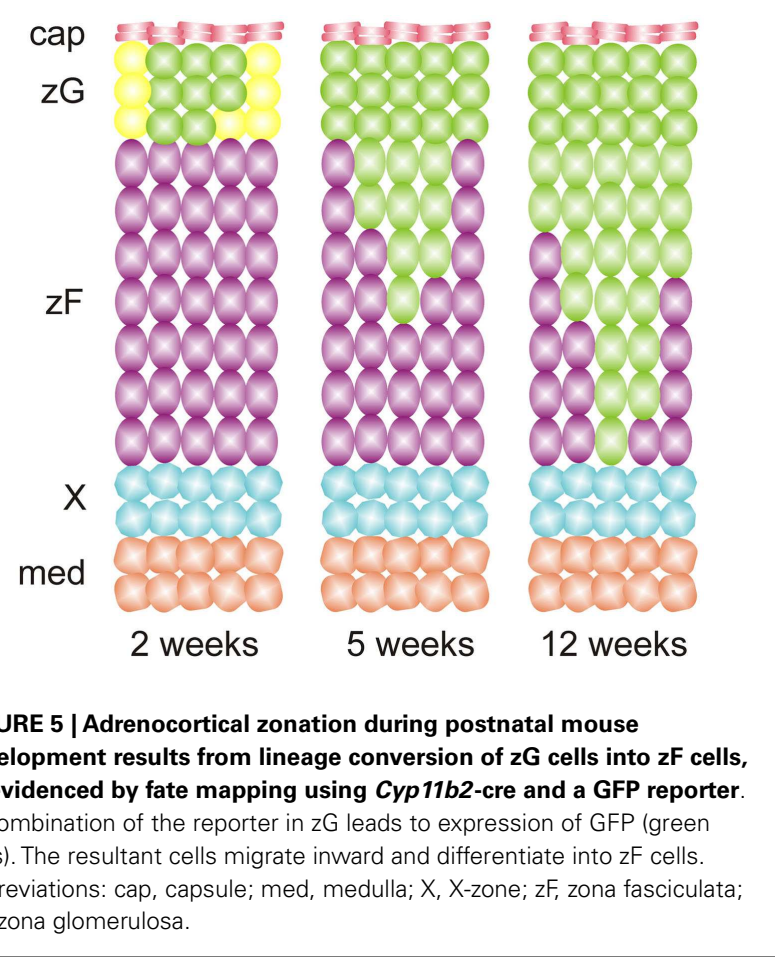

DEVELOPMENTAL SIGNALING PATHWAYS IMPLICATED IN ADRENOCORTICAL ZONATION, RENEWAL, OR REMODELING

Developmental signaling pathways control cell pluripotency, differentiation, and patterning in various tissues. As detailed below, some of these signaling pathways play key roles during the exponential growth phase of adrenal cortex development (12, 24, 43, 44). Additionally, these pathways regulate renewal and remodeling in the adult organism.

\section{HEDGEHOG PATHWAY}

The hedgehog family of morphogens comprises sonic hedgehog (SHH), Indian hedgehog, and desert hedgehog. Each of these ligands binds to Patched-1 (PTCH1), a transmembrane receptor that is expressed on target cells (45). In the absence of hedgehog binding, PTCH1 inhibits the G protein-coupled receptor Smoothened (SMO) [reviewed in Ref. $(2,46)]$. As a result, the zinc finger transcription factors GLI2 and GLI3 are proteolytically digested and lose their activation domains (47). The resultant truncated forms of GLI2 and GLI3 repress transcription. Binding of hedgehog ligands to PTCH1 relieves the inhibition it exerts on SMO, thereby preventing the proteolytic processing of the GLI factors. Fulllength GLI2 and GLI3 act as transcriptional activators. The related transcriptional activator, GLI1, is not expressed in the absence of hedgehog ligand, but is upregulated by activation of the pathway. Consequently Gli1 expression serves as a useful marker for active hedgehog signaling (48).

$\mathrm{SHH}$, the only member of the hedgehog family produced in the adrenal cortex, is secreted by subcapsular cells that express $S f 1$ but not the terminal enzymes required for corticoid synthesis $(30,41,49)$. Capsular cells, which do not express $S f 1$, respond to $\mathrm{SHH}$ by expressing Gli1 (Figure 6). Some of these GLI1 ${ }^{+}$capsule

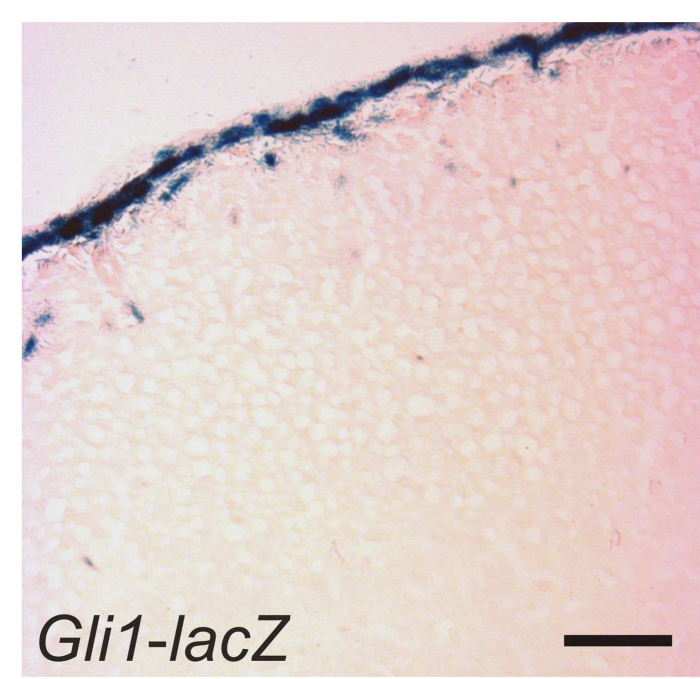

FIGURE 6 | $\mathrm{GLI1}^{+}$cells in the adrenal capsule. An adrenal gland from a 1-month-old female Gli1-lacZ mouse was whole mount stained with X-gal, cryosectioned, and counterstained with eosin. Bar, $50 \mu \mathrm{m}$.

cells migrate centripetally into the cortex, lose responsiveness to $\mathrm{SHH}$, and become steroidogenic, as evidenced by upregulation of $S f 1$ and differentiation markers characteristic of the $\mathrm{zG}$ (Cyp11b2) or zF (Cyp11b1) (Table 2). GLI1 ${ }^{+}$progenitor cells efficiently contribute to steroidogenic lineages during the exponential phase of cortical growth in embryo, fetus, and newborn mouse (30). In the adult mouse, $\mathrm{GLI}^{+}$progenitors contribute to the cortex with low efficiency, but the pathway can be activated in the adult following experimental manipulations such as dexamethasone-induced cortical atrophy. Conditional deletion of Shh in steroidogenic cells of the mouse adrenal results in cortical hypoplasia and capsular thinning, but does not cause major alterations in zonation $(30,41,49)$.

\section{DELTA-LIKE HOMOLOG 1 PATHWAY}

A related signaling protein implicated in adrenocortical homeostasis is Delta-like homolog 1 (DLK1). This factor, also known as preadipocyte factor-1 (PREF-1), is a transmembrane protein related to the Notch family of signaling molecules. DLK1 was originally identified as an important regulator of the undifferentiated state in preadipocytes (50). Cleavage of the extracellular domain of DLK1 by TNF- $\alpha$ converting enzyme produces a biologically active soluble peptide that inhibits the differentiation of preadipocytes into mature adipocytes (50). Subsequent studies showed that DLK1 controls the quiescence of stem/progenitor cells in not only adipose tissue but also other tissue types, including the adrenal cortex $(12,50)$.

Adrenal enucleation experiments have shown that $D l k 1$ expression is downregulated and not re-established until zonation of the cortex is complete, suggesting that DLK1 is a negative regulator of adrenocortical differentiation (51). Dlkl is co-expressed with $S h h$ in the outer zU of the rat (Figure 7) (12). Soluble DLK1, like SHH, modulates Gli1 expression in nearby capsule cells. In addition to being co-expressed, $D l k l$ and Shh are coordinately regulated (12). 
Both genes are downregulated in the adrenals of mice fed a low $\mathrm{Na}^{+}$diet. Conversely, Dlkl and Shh are upregulated in the adrenals of mice treated with captopril. These findings suggest that DLK1 and $\mathrm{SHH}$ may act together to fine tune the activation of signal receiving cells in the adrenal capsule of the rat. The expression pattern of $D l k 1$ differs between rats and mice; in mice $D l k 1$ is expressed in the adrenal capsule rather than the underlying cortex. Nevertheless, indirect evidence suggests that in mice, as in

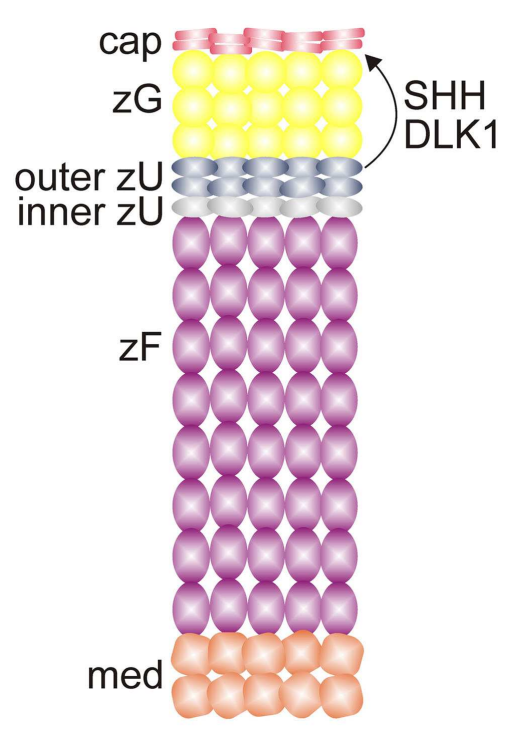

FIGURE 7 | SHH and DLK1 are co-expressed in the outer $\mathrm{zU}$ of the rat adrenal cortex and may act in concert to regulate stem/progenitor cells in the adrenal capsule. Abbreviations: cap, capsule; DLK1, delta-like homolog-1; med, medulla; $\mathrm{SHH}$, sonic hedgehog; X, X-zone; zF, zona fasciculata; $z \mathrm{G}$, zona glomerulosa; $z \mathrm{U}$, undifferentiated zone. rats, DLK1 may negatively regulate the differentiation of GLI1 ${ }^{+}$ capsular progenitor cells (43).

\section{FIBROBLAST GROWTH FACTOR PATHWAY}

Mouse genetic studies have implicated the FGF signaling pathway in adrenocortical development and maintenance [reviewed in Ref. $(2,43)]$. The FGF family comprises a large group of extracellular ligands that signal through a family of tyrosine kinase receptors, the FGF receptors (FGFRs). In mammals, the FGFR family consists of four genes, FGFR1-4, which undergo alternative splicing to generate an array of receptors that differ in ligand affinities (52). In the presence of heparin, FGFs bind to their cognate receptors, promoting receptor dimerization and autophosphorylation. This in turn stimulates downstream signaling pathways, including the phosphatidylinositol 3-kinase (PI3K), Janus kinase and signal transducer and activator of transcription (JAK-STAT), and mitogen-activated protein kinase (MAPK) pathways. FGF signaling is essential for proper patterning of the embryo, and this pathway participates in stem cell maintenance (53). Factors in the FGF pathway are expressed in both the adrenal capsule and cortex, as summarized in Table 4.

\section{WNT/B-CATENIN SIGNALING}

$\beta$-catenin exists in two pools: a cytoskeletal pool controls the interaction of cadherin complexes with adherens junctions, while a cytoplasmic pool participates in canonical WNT signaling, acting as a co-activator for transcription factors of the TCF/LEF family [reviewed in Ref. (2)]. Transcriptionally active $\beta$-catenin has been demonstrated in the AGP, the adrenal primordium, and adrenal subcapsular cells of the fetus and adult (61) (Figure 8). $\mathrm{WNT} / \beta$-catenin signaling is thought to maintain the undifferentiated state of adrenocortical stem/progenitor cells $(7,62)$. Targeted mutagenesis of $\beta$-catenin in $\mathrm{SF}^{+}$cells causes late onset adrenal hypoplasia, presumed to be the result of stem/progenitor cell pool

Table 4 | FGF ligands and receptors implicated in adrenocortical cell development and homeostasis.

\begin{tabular}{|c|c|c|c|c|}
\hline & Protein & Location & Comments & Reference \\
\hline \multirow[t]{3}{*}{ Ligands } & FGF1 & Cortex & This isoform activates FGFR2 IIIb & (43) \\
\hline & FGF2 & Capsule & $\begin{array}{l}\text { FGF2, which activates FGFR1 IIIc, acts as a mitogen for adrenocortical cells both in culture } \\
\text { and in gland regeneration experiments and has been shown to bind specifically to cells } \\
\text { from the } z G\end{array}$ & $(43,54-58)$ \\
\hline & FGF9 & Capsule & This isoform activates FGFR1 IIIc & (43) \\
\hline \multirow[t]{4}{*}{ Receptors } & FGFR1 IIIC & $\begin{array}{l}\text { Capsule } \\
\text { and cortex }\end{array}$ & $\begin{array}{l}\text { This FGFR isoform is expressed in both capsule and cortex, although its precise role in } \\
\text { adrenocortical development is unknown }\end{array}$ & (43) \\
\hline & FGFR2 IIIb & Cortex & $\begin{array}{l}\text { Like SHH and } \beta \text {-catenin, this FGFR isoform is expressed in the subcapsular region; } \\
\text { embryos with a global Fgfr2 I/lb deletion have hypoplastic adrenal glands, impaired } \\
\text { steroidogenesis, and thickened adrenal capsules with increased Gli1 expression }\end{array}$ & $(43,59)$ \\
\hline & FGFR2 IIIC & Cortex & $\begin{array}{l}\text { Like } \mathrm{SHH} \text { and } \beta \text {-catenin, this FGFR isoform is expressed in clusters of cells in the } \\
\text { subcapsular region. Deletion of both FGFR2 isoforms in steroidogenic tissues leads to } \\
\text { hypoplastic adrenals }\end{array}$ & $(43,60)$ \\
\hline & FGFR3 IIIC & Cortex & $\begin{array}{l}\text { This isoform is expressed in cortex, although its precise role in adrenocortical development } \\
\text { is unknown }\end{array}$ & (43) \\
\hline
\end{tabular}




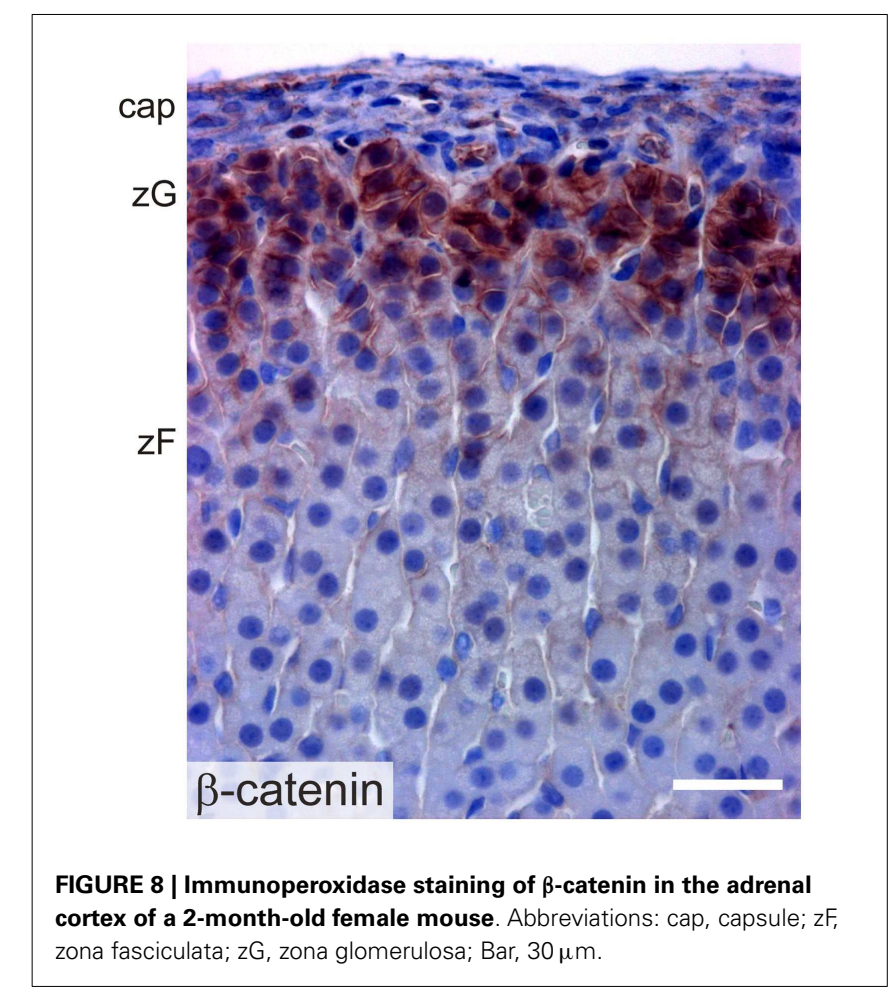

depletion (61). On the other hand, constitutive activation of $\beta$ catenin in steroidogenic cells expressing aldo-keto reductase family 1, member B7 (Akr1b7) causes abnormal accumulation of undifferentiated cells in the capsule and subcapsule and a concomitant increase in Shh mRNA expression (40).

Regulation of the WNT/ $\beta$-catenin pathway is complex and entails not only a family of WNT ligands but also multiple receptors, co-receptors, decoy receptors, and other modulators (Table 5). This complexity allows fine tuning of the response to morphogen gradients. Stem cell self-renewal mechanisms are frequently co-opted to drive oncogenesis, and WNT signaling is the pathway most frequently mutated in adrenocortical carcinomas (63) (Table 5).

In addition to its proposed role in stem cell maintenance and recruitment, the $\mathrm{WNT} / \beta$-catenin pathway has been implicated in tissue patterning in the adult organism. For example, proper zonation of the liver requires restriction of WNT/ $\beta$-catenin signaling to hepatocytes near the central vein (64). In an analogous fashion, restriction of WNT signaling to the periphery of the adrenal cortex is thought to direct zonation in this tissue. Constitutive activation of $\beta$-catenin signaling in the mouse $\mathrm{zF}$ using Akr1b7-cre triggers the ectopic expression of the $\mathrm{zG}$ marker Cyp11b2 and increased production of aldosterone $(40,65)$. Moreover, studies have shown that $\beta$-catenin directly regulates the expression of genes critical for zG function, including At1r and Cyp11b2 (66).

Recent studies have shown that proper differentiation of $z F$ cells requires suppression of WNT/ $\beta$-catenin signaling (67). In vitro treatment of a $\mathrm{zF}$ cell line (ATCL7) with a chemical inducer of canonical WNT signaling (BIO) resulted in downregulation of genes essential for $\mathrm{zF}$ function, including $M c 2 r$,
Cyp11al, and Cyp11b1 (68). Promoter analyses suggested that the molecular basis for this repression may involve the displacement of SF 1 from steroidogenic gene promoters by $\beta$-catenin (68). These experiments also identified CCDC80 as a novel secreted inhibitor of zF steroidogenesis. Collectively these studies suggest that coordinated regulation of $\mathrm{WNT} / \beta$-catenin signaling is critical for adrenocortical patterning; WNT/ $\beta$-catenin signaling must be active for $\mathrm{zG}$ determination and must be extinguished for $\mathrm{zF}$ determination.

\section{OTHER SIGNALING PATHWAYS IMPLICATED IN ADRENOCORTICAL GROWTH AND REMODELING}

Adrenocortical growth and homeostasis are controlled by a diverse array of endocrine/paracrine factors, including ACTH, Ang II, and insulin-related growth factors (IGFs) $(15,24)$. Hormones traditionally associated with reproductive function, including luteinizing hormone ( $\mathrm{LH})$, activin, inhibin, and prolactin, also influence the differentiation and function of adrenocortical cells [reviewed in Ref. (15)].

\section{cAMP SIGNALING}

Many of the hormones that regulate adrenocortical cell proliferation bind to G-protein coupled receptors on the surface of cells [reviewed in Ref. (38)]. Activation of these receptors stimulates adenylate cyclase, resulting in cAMP production. cAMP binds to the regulatory subunits of PKA, allowing the catalytic subunits of protein kinase A (PKA) to phosphorylate downstream effectors, including transcription factors that enhance expression of steroidogenic genes (38).

Inactivating mutations in the protein kinase-A regulatory subunit gene (PRKAR1A) lead to excessive cAMP production. Such mutations cause Carney complex, a syndrome associated with pituitary-independent Cushing syndrome and adrenocortical neoplasia. Conditional deletion of Prkarla in the adrenal cortex of mice (using Akrlb7-cre) leads to disrupted stem/progenitor cell differentiation, excess cell proliferation, and impaired apoptosis in the adrenal cortex (37). This resistance to apoptosis is mediated in part by crosstalk between the PKA and mammalian target of rapamycin (mTOR) pathways (39). As these mice age, a new zone composed of cells that express Cyp17a1 and secrete cortisol appears in the inner aspect of the cortex. This ectopic X-like zone is thought to arise from normally dormant stem/progenitor cells in the juxtamedullary region $(37,38)$. These studies and others (38) indicate that normal adrenocortical cell differentiation and proliferation require proper regulation of PKA activity.

\section{IGF SIGNALING}

This pathway has been implicated in growth and differentiation of adrenocortical cells. The IGF family consists of two ligands, IGF1 and IGF2, which bind to the receptor tyrosine kinase IGF1R and promote mitosis/survival via signaling through the MAPK and PI3K pathways $(76,77)$. IGF1 and IGF2 are expressed at comparable levels in the adult adrenal cortex, whereas IGF2 is highly and preferentially expressed in the fetal adrenal cortex. IGF1R is enriched in the subcapsular region (78). The activity of IGFs is modulated by a family of six IGF-binding proteins (IGFBPs), which can bind and either stimulate or inhibit the activity of IGFs (76). 
Table 5 | Factors implicated in WNT/ $\beta$-catenin signaling in the adrenal cortex.

\begin{tabular}{|c|c|c|c|}
\hline Factor & Function & Adrenocortical phenotypes & Reference \\
\hline WNT4 & Ligand that activates signaling & $\begin{array}{l}\text { Wnt4 }{ }^{-/} \text {mice have impaired } z G \text { differentiation and } \\
\text { decreased aldosterone production }\end{array}$ & (69) \\
\hline Frizzled (FZD) & Receptor for WNTs & & $(70)$ \\
\hline $\begin{array}{l}\text { LDL receptor-related proteins } \\
5 \text { and } 6 \text { (LRP5/6) }\end{array}$ & Co-receptors for WNTs & & $(44)$ \\
\hline R-spondin-3 (RSPO3) & Ligand that potentiates WNT signaling & & $(71)$ \\
\hline $\begin{array}{l}\text { Leucine-rich repeat containing } \\
\text { G protein-coupled receptor } \\
5 \text { (LGR5) }\end{array}$ & $\begin{array}{l}\text { Receptor for RSPO3; inhibits the activity } \\
\text { of ZNRF3 }\end{array}$ & & $(72)$ \\
\hline Zinc and ring finger 3 (ZNRF3) & $\begin{array}{l}\text { E3 ubiquitin ligase that inhibits signaling } \\
\text { by promoting the degradation of FZD/LRP }\end{array}$ & $\begin{array}{l}\text { Somatic mutations in ZNRF3 are common in human } \\
\text { adrenocortical carcinomas }\end{array}$ & $(73)$ \\
\hline $\begin{array}{l}\text { Secreted frizzled related } \\
\text { proteins (SFRP1/2) }\end{array}$ & $\begin{array}{l}\text { Decoy receptors that inhibit signaling by } \\
\text { sequestering WNT ligands away from } \\
\text { activating receptors }\end{array}$ & $\begin{array}{l}\text { The Sfrp } 1 \text { locus has been linked to GDX-induced } \\
\text { adrenocortical neoplasia in the mouse; decreased } \\
\text { expression of SFRP2 is associated with } \\
\text { aldosterone-producing adenoma development }\end{array}$ & $(66,74)$ \\
\hline Dickkopf-3 (DKK3) & Inhibits signaling by interacting with LRPs & $\begin{array}{l}D k k 3 \text { expression is greater in the } z \mathrm{G} \text { than in other } \\
\text { zones. Genetic studies indicate that } D k k 3 \text { regulates } \\
\text { aldosterone biosynthesis }\end{array}$ & $(70,75)$ \\
\hline $\begin{array}{l}\text { Kringle containing } \\
\text { transmembrane protein } \\
1 \text { (KREMEN1) }\end{array}$ & $\begin{array}{l}\text { Inhibits signaling by binding DKK3 and } \\
\text { LRPs and inducing internalization of FZD }\end{array}$ & $\begin{array}{l}\text { Somatic mutations in KREMEN1 are common in } \\
\text { human adrenocortical carcinomas }\end{array}$ & (63) \\
\hline
\end{tabular}

Mice deficient in both the Igf1r and the insulin receptor (Insr) genes exhibit adrenal agenesis and male-to-female sex reversal (79). The AGP of the double knockout mice contains half the number of $\mathrm{SF}^{+}$cells found in wild-type mice. These data indicate that IGF signaling is pivotal for adrenocortical cell specification. Additionally, IGFs have been shown to enhance basal and ACTH-induced steroidogenesis in fetal and adult adrenocortical cells (80).

\section{TRANSFORMING GROWTH FACTOR $\boldsymbol{\beta}$ SIGNALING}

The Transforming growth factor $\beta$ (TGF- $\beta$ ) signaling pathway has been implicated in the maintenance and differentiation of stem/progenitor cells (81). The TGF- $\beta$ superfamily consists of a diverse array of ligands. Two members of this family, activin and inhibin, are expressed in the fetal and adult adrenal cortex, and have been shown to regulate the growth, function, and survival of adrenocortical cells. Activin signaling is mediated by type I and type II receptors, which are integral membrane receptor serine/threonine kinases. Intracellular SMAD proteins transduce signals from these receptors to the nucleus (81). Activin has been shown to inhibit adrenocortical cell growth, enhance apoptosis of $\mathrm{X}$-zone cells, and modulate steroidogenesis $(23,82,83)$. By binding beta-glycan and ActRIA, inhibin blocks activin binding to the type II receptor and subsequent recruitment of the signaling type I receptor (83).

Following GDX, ovarian-like tissue accumulates in the adrenal cortex of Inha ${ }^{-/-}$mice in an LH dependent manner $(23,84,85)$. The loss of Inha results in constitutive TGF- $\beta 2$ activation in adrenocortical progenitor cells, with subsequent expansion of cells that express Gata4 and other gonadal-like markers. Thus, Inha impacts cell fate decisions (adrenal vs. gonadal) in adrenal cortex.

\section{LH SIGNALING}

This glycoprotein hormone is composed of a common gonadotropin $\alpha$-subunit and hormone-specific $\beta$-subunit. $\mathrm{LH}$ is secreted from the pituitary in response to gonadotropin releasing hormone $(\mathrm{GnRH})$. LH binds to G-protein-coupled surface receptor, LHCGR, present on gonadal steroidogenic cells and activates downstream signals, including the cAMP/PKA, MAPK, and PI3K pathways (15). This in turn leads to enhanced expression of steroidogenic enzyme genes, resulting in increased production of sex steroids. Activation of LHCGR also has pleiotropic effects on cell growth and differentiation.

Cells in the adrenal glands express LHCGR and can respond to surges in LH, as evidenced by the phenomenon of GDX-induced adrenocortical neoplasia (71). Following GDX, gonadal-like neoplasms accumulate in the subcapsular region of the adrenal cortex of certain strains of mice. This phenomenon is thought to reflect LH-induced metaplasia of stem/progenitor cells in the adrenal cortex, although the term "neoplasia" is used more often than "metaplasia" to describe the process, because with time these lesions can evolve into frank adenomas or carcinomas. The neoplastic cells express gonadal-like markers (e.g., Lhcgr, Gata4, and Cyp17a1) and secrete sex steroids (86). This phenomenon occurs 
in other species such as ferrets and goats [reviewed in Ref. (71)]. Moreover, adrenocortical tumors with histologic features resembling luteinized ovarian stroma ("thecal metaplasia") have been reported, albeit rarely, in postmenopausal women and men with acquired testicular atrophy. Genetic and pharmacologic experiments using mice or ferrets support the premise that LH has a central role in GDX-induced adrenocortical neoplasia [reviewed in Ref. $(15,71)]$. The formation of ectopic gonadal-like tissue in the adrenal gland can be viewed as an extreme example of adrenocortical remodeling in response to $\operatorname{GDX}(13,25)$.

\section{TRANSCRIPTION FACTORS IMPLICATED IN RENEWAL AND REMODELING \\ SF1}

SF1 is a master regulator of adrenocortical development and the prototype of steroidogenic transcription factors. SF1 regulates a wide array of genes required for steroidogenic cell function (87, 88). Traditionally, SF1 has been classified as an orphan nuclear receptor, but recent studies have shown that certain phospholipids and sphingolipids bind and regulate this transcription factor [reviewed in Ref. (89)]. For example, the activity of SF1 can be modulated by phosphorylation of the 3-position of the inositol head group of phosphatidylinositol-4,5-bisphosphate $\mathrm{PI}(4,5) \mathrm{P}_{2}$ while this phospholipid is bound to SF1 (90). Thus, it is hypothesized that multiple bioactive lipids function as ligands for SF1 and differentially regulate SF1 activity in a context-dependent manner (89).

$S \mathrm{SI}^{-/-}$mice exhibit degeneration of the AGP due to apoptosis, which results in agenesis of both the adrenal glands and gonads (91). Similarly, targeted mutagenesis of transcription factors that activate $S f 1$ expression, such as $W t 1, P b x 1$, and Cited, severely impairs adrenal gland development [reviewed in Ref. $(25,26,92)]$. $S f 1^{ \pm}$mice have small adrenal glands, reduced corticosterone production in response to stress, and impaired compensatory growth response following unilateral adrenalectomy $(91,93)$. Individuals with mutations in the DNA-binding domain of SF1 exhibit primary adrenal failure and gonadal dysgenesis. In addition to regulating steroidogenesis, this transcription factor has been implicated in the control of other fundamental cellular processes including glycolysis $(87,88)$.

Mice harboring multiple copies of $S f 1$, mimicking the amplification of $S f 1$ seen in childhood adrenocortical carcinoma $(94,95)$, develop adrenocortical neoplasms that express gonadal-like markers. This suggests that SF1 can influence cell fate determination. Intriguingly, genetic ablation of the SF1 target gene Vnn1, encoding the gonadal-like marker Vanin-1, has been shown to reduce the severity of neoplastic lesions in the Sf1 transgenic mice (96). Similarly, mice in which the endogenous $S f 1$ gene of the mouse has been replaced with a mutant lacking a key SUMOylation site exhibit abnormal cell fate specification in steroidogenic tissues, including ectopic expression of gonadal markers (97). The mutant mice also exhibit persistence of the X-zone (97).

\section{DOSAGE-SENSITIVE SEX REVERSAL, ADRENAL HYPOPLASIA CRITICAL REGION ON CHROMOSOME X (DAX1)}

The activity of SF1 is modulated by Daxl (also called NrOb1), an $\mathrm{X}$-linked gene that encodes a repressor of steroidogenic gene expression (98). In response to ACTH, SF1-positive subcapsular progenitors downregulate Daxl and differentiate into adrenocorticoid-producing cells. DAX1 deficiency in humans and mice leads to excessive differentiation of subcapsular progenitors and eventual depletion of the stem/progenitor cell compartment (99, 100). Cytomegaly, a hallmark of adrenal dysfunction associated with Dax1 deficiency $(98,99,101)$, is thought to be a compensatory response to a reduced number of cortical cells or to progenitor cell exhaustion (100).

\section{TCF21}

TCF21 (also known as POD1) is a basic helix-loop-helix transcription factor functions as a repressor of $S f 1$ (102). Tcf21 is expressed in the adrenal capsule of adult mice (103), and adrenal glands from $T c f 21^{-/-}$mice exhibit ectopic expression of Sf1 in the capsule (103). As mentioned previously, some capsule cells are derived from progenitors in the fetal adrenal cortex, and it has been proposed that TCF21 downregulates $S f 1$ expression in these cells upon recruitment into the capsule (27). Lineage tracing studies have shown that TCF $21^{+}$capsular cells give rise to non-steroidogenic stromal cells in the adrenal cortex, but not to steroidogenic cells (27). Collectively these studies suggest that TCF $21^{+}$cells in the adrenal capsule participate in adrenocortical homeostasis.

\section{WT1}

Fate mapping studies of $\mathrm{WT}^{+}{ }^{+}$cells have identified long-lived progenitor population in the adrenal capsule characterized by expression of $W t 1$ and Gata4, markers of the AGP $(25,104)$. Under basal conditions these AGP-like cells give rise to normal adrenocortical cells (Figure 9). GDX activates these $\mathrm{WT}^{+}{ }^{+}$progenitors and drives their differentiation into gonadal-like steroidogenic tissue. Hence, $\mathrm{WT}^{+}{ }^{+}$capsular cells represent a reserve stem/progenitor cell population with AGP-like features that can be mobilized in response to extreme physiological demand (i.e., the hormonal changes associated with GDX).

In the mouse embryo $W t 1$ repression is necessary for proper expression of $S f 1$ and differentiation of stem/progenitor cells into adrenocortical cells $(25,104)$. Ectopic expression of a transcriptionally active isoform of WT1 in $\mathrm{SF}^{+}$progenitors causes adrenocortical hypoplasia, increased expression of Gata4, Gli1, and Tcf21, and contraction of the X-zone. WT1 directly regulates the expression of Gli1 in adrenal tissue suggesting that ectopic expression of $W t 1$ prevents differentiation into $\mathrm{SF}^{+}$adrenocortical steroidogenic cells by maintaining cells in a $\mathrm{GLI}^{+}$progenitor state.

\section{GATA BINDING PROTEIN-6 (GATA6)}

This transcription factor is expressed in the adrenal cortex of the fetal mouse (105). Postnatally, adrenal expression of Gata6 is limited to capsular and subcapsular cells (106). Targeted deletion of Gata6 in $\mathrm{SF}^{+}$cells results in a pleiotropic adrenal phenotype that includes a thin adrenal cortex, cytomegaly, blunted corticoid production, ectopic chromaffin cells, and aberrant expression of gonadal-like markers (106). Thus, GATA6 is thought to limit the differentiation of adrenal stem/progenitor cells into gonadal-like cells.

Gata6 mutant mice also exhibit abnormal adrenocortical zonation: virgin females lack an $\mathrm{X}$-zone, and castrate males lack a 
secondary X-zone (Figures 10A,B) (106). Gata6 is not expressed in the X-zone of postnatal wild-type mice, arguing that the effect of Gata6 ablation on X-zone development is either a non-cell autonomous phenomenon or that it occurs in fetal adrenal cells that co-express Gata6 and Sf1-cre (106). Recently, Sergei Tevosian's laboratory reported that Gata4/Gata6 double knockout mice generated with $S f 1$-cre exhibit severe adrenal hypoplasia; female double knockout mice die from adrenocortical insufficiency, whereas their male counterparts survive due to heterotopic glucocorticoid production by cells in the testes (107).

Circumstantial evidence from other organ systems suggests that GATA6 may modulate developmental signaling pathways in the adrenal cortex. In epithelial cells of the lung and intestine, GATA6 interacts with the $\mathrm{WNT} / \beta$-catenin and TGF- $\beta$ signaling pathways

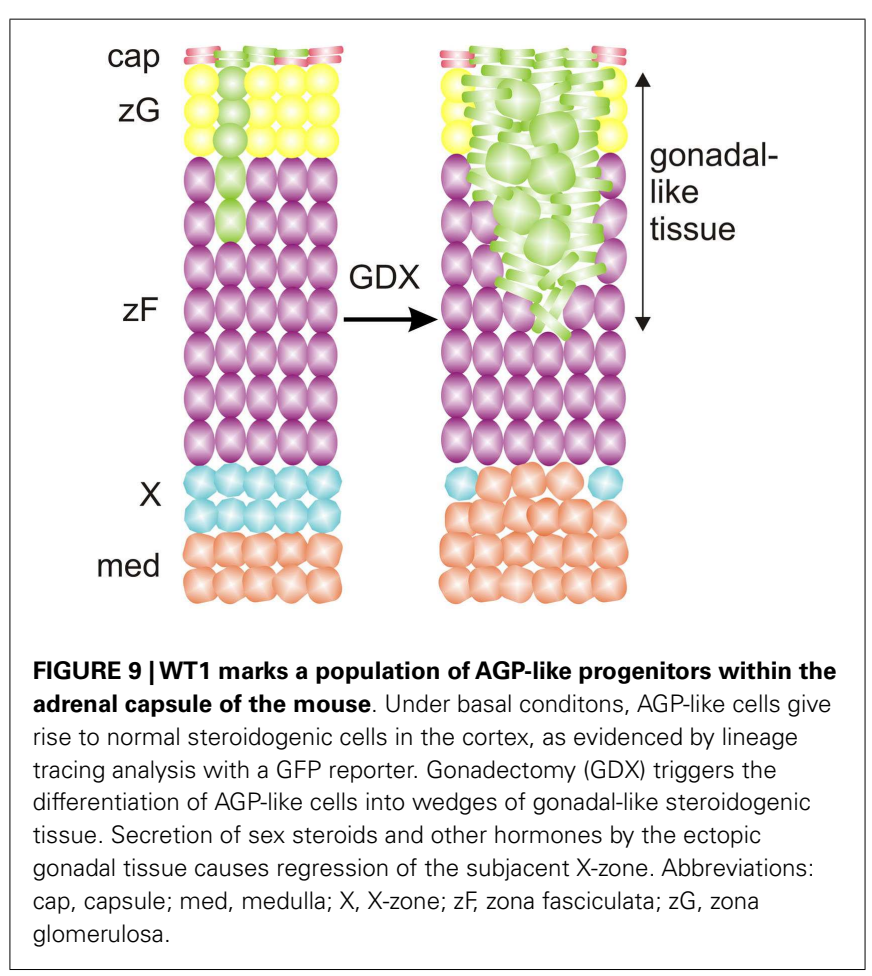

to regulate the balance between stem/progenitor cell expansion and differentiation (108-113). Hindlimb buds express Gata6 in an anterior-posterior gradient, and conditional deletion of Gata6 in limb bud mesenchyme of mice leads to ectopic expression of Shh and its target gene Gli1. The mutant mice develop hindlimb preaxial polydactyly. Conversely, enforced expression of Gata6 in the limb bud represses expression of Shh and results in hypomorphic limbs. In an analogous fashion, GATA6 may repress transcription of Shh and Gli1 in the adrenal cortex. Consistent with this notion, Gli1 has been shown to be upregulated in the adrenal glands of gonadectomized Gata6 $6^{\text {flox/flox; }}$;Sf1-cre mice (106).

\section{SUMMARY AND PERSPECTIVES}

The continual remodeling of the zones of the adrenal cortex requires the precise control of cell growth and differentiation. The process involves distinct pools of stem/progenitor cells in the capsule, subcapsule, and elsewhere. Direct lineage conversion of mature steroidogenic cells is also integral to adrenocortical zonation and remodeling. The pathways involved are complex and redundant so as to fulfill the offsetting goals of organ homeostasis and stress adaptation. Disruption of these pathways can lead to neoplasia.

Although much has been learned about the regulation of adrenocortical homeostasis and regeneration, there are still many unanswered questions. It has proven difficult to isolate and characterize adrenocortical stem cell populations, and we do not know how these populations vary with age. Nor do we understand the relative contributions of the hedgehog, DLK1, FGF, and WNT/ $\beta$ catenin signaling pathways to adrenocortical differentiation, or how these pathways interface with classic endocrine signaling systems, such as the RAAS and the HPA axis. The positional cues that mediate differentiation during centripetal (or centrifugal) migration also remain enigmatic. In other epithelial organs (e.g., liver, intestine, and lung) the development of in vitro systems, such as organoid cultures and induced pluripotent stem cell models, has helped to elucidate the regulation of differentiation (114). To date, there has been little progress in the development of in vitro models to study adrenocortical differentiation. Hopefully, such techniques will emerge in the coming years and help drive the field forward.

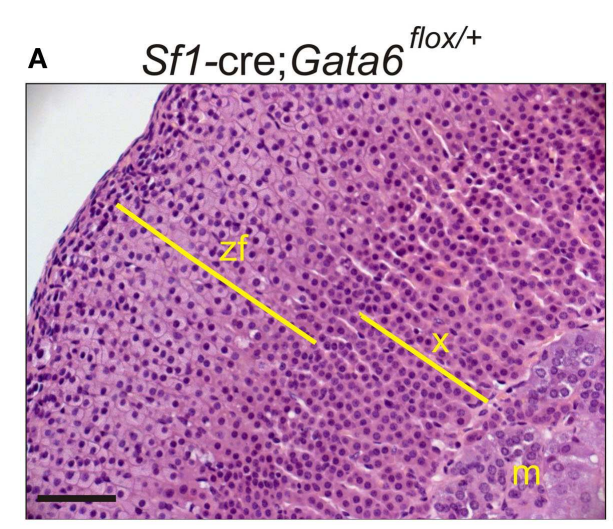

FIGURE 10 | GATA6 is required for formation of a secondary $X$-zone (A,B) 3-week-old Sf1-cre; Gata6 flox/+ or Sf1-cre; Gata6 floxfllox mice were orchiectomized. Adrenal tissue was harvested 1 month later, and paraffin

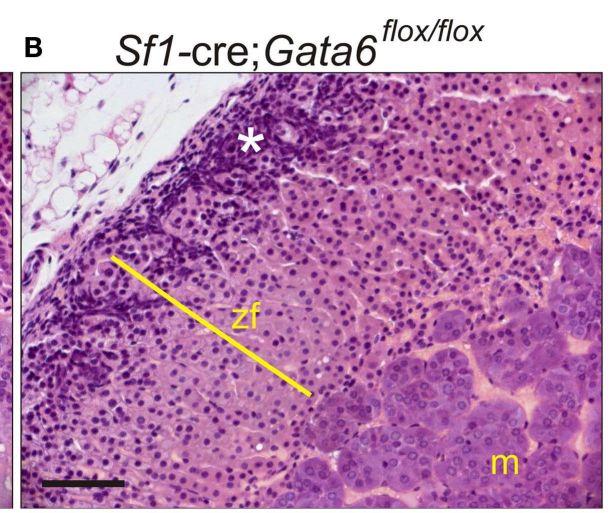

sections were stained with $\mathrm{H} \& \mathrm{E}$. Note the absence of a secondary $\mathrm{X}$-zone in the mutant mice. The asterisk highlights gonadal-like cells in the subcapsular region. Bar, $50 \mu \mathrm{m}$. 


\section{ACKNOWLEDGMENTS}

This work was supported by the following funding agencies: American Heart Association (13GRNT16850031) to DW, DOD (PC141008) to DW, NIH (DK52574) supporting the histology core laboratory at Washington University, Sigrid Jusélius Foundation to $\mathrm{MH}$, and the Academy of Finland to $\mathrm{MH}$.

\section{REFERENCES}

1. Miller WL, Auchus RJ. The molecular biology, biochemistry, and physiology of human steroidogenesis and its disorders. Endocr Rev (2011) 32(1):81-151. doi:10.1210/er.2010-0013

2. Yates R, Katugampola H, Cavlan D, Cogger K, Meimaridou E, Hughes C, et al. Adrenocortical development, maintenance, and disease. Curr Top Dev Biol (2013) 106:239-312. doi:10.1016/B978-0-12-416021-7.00007-9

3. Mitani F. Functional zonation of the rat adrenal cortex: the development and maintenance. Proc Jpn Acad Ser B Phys Biol Sci (2014) 90(5):163-83. doi:10.2183/pjab.90.163

4. Walczak EM, Hammer GD. Regulation of the adrenocortical stem cell niche: implications for disease. Nat Rev Endocrinol (2015) 11(1):14-28. doi:10.1038/ nrendo.2014.166

5. Zelander T. The ultrastructure of the adrenal cortex of the mouse. Z Zellforsch Mikrosk Anat (1957) 46(6):710-6. doi:10.1007/BF00339373

6. Nussdorfer GG. Cytophysiology of the adrenal cortex. Int Rev Cytol (1986) 98:1-405.

7. Simon DP, Hammer GD. Adrenocortical stem and progenitor cells: implications for adrenocortical carcinoma. Mol Cell Endocrinol (2012) 351(1):2-11. doi:10.1016/j.mce.2011.12.006

8. Beuschlein F, Galac S, Wilson DB. Animal models of adrenocortical tumorigenesis. Mol Cell Endocrinol (2012) 351(1):78-86. doi:10.1016/j.mce.2011.09.045

9. Morohashi K, Zubair M. The fetal and adult adrenal cortex. Mol Cell Endocrinol (2011) 336(1-2):193-7. doi:10.1016/j.mce.2010.11.026

10. Hirokawa N, Ishikawa $\mathrm{H}$. Electron microscopic observations on postnatal development of the $\mathrm{X}$ zone in mouse adrenal cortex. Z Anat Entwicklungsgesch (1974) 144(1):85-100. doi:10.1007/BF00518635

11. Hershkovitz L, Beuschlein F, Klammer S, Krup M, Weinstein Y. Adrenal 20alpha-hydroxysteroid dehydrogenase in the mouse catabolizes progesterone and 11-deoxycorticosterone and is restricted to the X-zone. Endocrinology (2007) 148(3):976-88. doi:10.1210/en.2006-1100

12. Guasti L, Cavlan D, Cogger K, Banu Z, Shakur A, Latif S, et al. Dlk1 upregulates Glil expression in male rat adrenal capsule cells through the activation of betal integrin and ERK1-2. Endocrinology (2013) 154(12):4675-84. doi:10.1210/en.2013-1211

13. Pihlajoki M, Heikinheimo M, Wilson DB. Never underestimate the complexity of remodeling. Endocrinology (2013) 154(12):4446-9. doi:10.1210/en.20131982

14. Gorrigan RJ, Guasti L, King P, Clark AJ, Chan LF. Localisation of the melanocortin-2-receptor and its accessory proteins in the developing and adult adrenal gland. J Mol Endocrinol (2011) 46(3):227-32. doi:10.1530/JME-110011

15. Bielinska M, Kiiveri S, Parviainen H, Mannisto S, Heikinheimo M, Wilson DB. Gonadectomy-induced adrenocortical neoplasia in the domestic ferret (Mustela putorius furo) and laboratory mouse. Vet Pathol (2006) 43(2):97-117. doi:10.1354/vp.43-2-97

16. Quinn TA, Ratnayake U, Dickinson H, Nguyen TH, McIntosh M, CastilloMelendez M, et al. Ontogeny of the adrenal gland in the spiny mouse, with particular reference to production of the steroids cortisol and dehydroepiandrosterone. Endocrinology (2013) 154(3):1190-201. doi:10.1210/en.2012-1953

17. Wagner S, Kiupel M, Peterson RA, Heikinheimo M, Wilson DB. Cytochrome b5 expression in gonadectomy-induced adrenocortical neoplasms of the domestic ferret (Mustela putorius furo). Vet Pathol (2008) 45(4):439-42. doi:10.1354/vp. 45-4-439

18. Bland ML, Desclozeaux M, Ingraham HA. Tissue growth and remodeling of the embryonic and adult adrenal gland. Ann N Y Acad Sci (2003) 995:59-72. doi:10.1111/j.1749-6632.2003.tb03210.x

19. Naffin-Olivos JL, Auchus RJ. Human cytochrome b5 requires residues E48 and E49 to stimulate the 17,20-lyase activity of cytochrome P450c17. Biochemistry (2006) 45(3):755-62. doi:10.1021/bi051623y
20. Pattison JC, Abbott DH, Saltzman W, Conley AJ, Bird IM. Plasticity of the zona reticularis in the adult marmoset adrenal cortex: voyages of discovery in the New World. J Endocrinol (2009) 203(3):313-26. doi:10.1677/JOE-08-0554

21. Topor LS, Asai M, Dunn J, Majzoub JA. Cortisol stimulates secretion of dehydroepiandrosterone in human adrenocortical cells through inhibition of 3betaHSD2. J Clin Endocrinol Metab (2011) 96(1):E31-9. doi:10.1210/jc.20100692

22. Hirokawa N, Ishikawa H. Electron microscopic observations on the castrationinduced X zone in the adrenal cortex of male mice. Cell Tissue Res (1975) 162(1):119-30. doi:10.1007/BF00223267

23. Beuschlein F, Looyenga BD, Bleasdale SE, Mutch C, Bavers DL, Parlow AF, et al. Activin induces $\mathrm{x}$-zone apoptosis that inhibits luteinizing hormone-dependent adrenocortical tumor formation in inhibin-deficient mice. Mol Cell Biol (2003) 23(11):3951-64. doi:10.1128/MCB.23.11.3951-3964.2003

24. Laufer E, Kesper D, Vortkamp A, King P. Sonic hedgehog signaling during adrenal development. Mol Cell Endocrinol (2012) 351(1):19-27. doi:10.1016/j. mce.2011.10.002

25. Bandiera R, Vidal VP, Motamedi FJ, Clarkson M, Sahut-Barnola I, von Gise A, et al. WT1 maintains adrenal-gonadal primordium identity and marks a population of AGP-like progenitors within the adrenal gland. Dev Cell (2013) 27(1):5-18. doi:10.1016/j.devcel.2013.09.003

26. Val P, Martinez-Barbera JP, Swain A. Adrenal development is initiated by cited 2 and Wt1 through modulation of Sf-1 dosage. Development (2007) 134(12):2349-58. doi:10.1242/dev.004390

27. Wood MA, Acharya A, Finco I, Swonger JM, Elston MJ, Tallquist MD, et al. Fetal adrenal capsular cells serve as progenitor cells for steroidogenic and stromal adrenocortical cell lineages in M. musculus. Development (2013) 140(22):4522-32. doi:10.1242/dev.092775

28. Schulte DM, Shapiro I, Reincke M, Beuschlein F. Expression and spatiotemporal distribution of differentiation and proliferation markers during mouse adrenal development. Gene Expr Patterns (2007) 7(1-2):72-81. doi:10. 1016/j.modgep.2006.05.009

29. Paul A, Laufer E. Endogenous biotin as a marker of adrenocortical cells with steroidogenic potential. Mol Cell Endocrinol (2011) 336(1-2):133-40. doi:10.1016/j.mce.2011.01.015

30. King P, Paul A, Laufer E. Shh signaling regulates adrenocortical development and identifies progenitors of steroidogenic lineages. Proc Natl Acad Sci U S A (2009) 106(50):21185-90. doi:10.1073/pnas.0909471106

31. Mitani F, Ogishima T, Miyamoto H, Ishimura Y. Localization of P450aldo and P45011 beta in normal and regenerating rat adrenal cortex. Endocr Res (1995) 21(1-2):413-23. doi:10.3109/07435809509030457

32. Mitani F, Mukai K, Miyamoto H, Suematsu M, Ishimura Y. Development of functional zonation in the rat adrenal cortex. Endocrinology (1999) 140(7):3342-53. doi:10.1210/en.140.7.3342

33. Monticone S, Auchus RJ, Rainey WE. Adrenal disorders in pregnancy. Nat Rev Endocrinol (2012) 8(11):668-78. doi:10.1038/nrendo.2012.155

34. Goto M, Piper HK, Marcos J, Wood PJ, Wright S, Postle AD, et al. In humans, early cortisol biosynthesis provides a mechanism to safeguard female sexual development. J Clin Invest (2006) 116(4):953-60. doi:10.1172/JCI25091

35. Morley SD, Viard I, Chung BC, Ikeda Y, Parker KL, Mullins JJ. Variegated expression of a mouse steroid 21-hydroxylase/beta-galactosidase transgene suggests centripetal migration of adrenocortical cells. Mol Endocrinol (1996) 10(5):585-98. doi:10.1210/me.10.5.585

36. Freedman BD, Kempna PB, Carlone DL, Shah MS, Guagliardo NA, Barrett PQ, et al. Adrenocortical zonation results from lineage conversion of differentiated zona glomerulosa cells. Dev Cell (2013) 26(6):666-73. doi:10.1016/j.devcel. 2013.07.016

37. Sahut-Barnola I, de Joussineau C, Val P, Lambert-Langlais S, Damon C, Lefrancois-Martinez AM, et al. Cushing's syndrome and fetal features resurgence in adrenal cortex-specific Prkarla knockout mice. PLoS Genet (2010) 6(6):e1000980. doi:10.1371/journal.pgen.1000980

38. de Joussineau C, Sahut-Barnola I, Levy I, Saloustros E, Val P, Stratakis CA, et al. The cAMP pathway and the control of adrenocortical development and growth. Mol Cell Endocrinol (2012) 351(1):28-36. doi:10.1016/j.mce.2011.10.006

39. de Joussineau C, Sahut-Barnola I, Tissier F, Dumontet T, Drelon C, BatisseLignier M, et al. mTOR pathway is activated by PKA in adrenocortical cells and participates in vivo to apoptosis resistance in primary pigmented nodular adrenocortical disease (PPNAD). Hum Mol Genet (2014) 23(20):5418-28. doi:10.1093/hmg/ddu265 
40. Berthon A, Sahut-Barnola I, Lambert-Langlais S, de Joussineau C, DamonSoubeyrand C, Louiset E, et al. Constitutive beta-catenin activation induces adrenal hyperplasia and promotes adrenal cancer development. Hum Mol Genet (2010) 19(8):1561-76. doi:10.1093/hmg/ddq029

41. Huang CC, Miyagawa S, Matsumaru D, Parker KL, Yao HH. Progenitor cell expansion and organ size of mouse adrenal is regulated by sonic hedgehog. Endocrinology (2010) 151(3):1119-28. doi:10.1210/en.2009-0814

42. Tetteh PW, Farin HF, Clevers H. Plasticity within stem cell hierarchies in mammalian epithelia. Trends Cell Biol (2015) 25(2):100-8. doi:10.1016/j.tcb.2014. 09.003

43. Guasti L, Candy Sze WC, McKay T, Grose R, King PJ. FGF signalling through Fgfr2 isoform IIIb regulates adrenal cortex development. Mol Cell Endocrinol (2013) 371(1-2):182-8. doi:10.1016/j.mce.2013.01.014

44. Parviainen H, Schrade A, Kiiveri S, Prunskaite-Hyyrylainen R, Haglund C, Vainio S, et al. Expression of Wnt and TGF-beta pathway components and key adrenal transcription factors in adrenocortical tumors: association to carcinoma aggressiveness. Pathol Res Pract (2013) 209(8):503-9. doi:10.1016/j.prp. 2013.06.002

45. Stone DM, Hynes M, Armanini M, Swanson TA, Gu Q, Johnson RL, et al. The tumour-suppressor gene patched encodes a candidate receptor for Sonic hedgehog. Nature (1996) 384(6605):129-34. doi:10.1038/384129a0

46. Finco I, LaPensee CR, Krill KT, Hammer GD. Hedgehog signaling and steroidogenesis. Annu Rev Physiol (2015) 77:105-29. doi:10.1146/annurev-physiol061214-111754

47. Pan Y, Bai CB, Joyner AL, Wang B. Sonic hedgehog signaling regulates Gli2 transcriptional activity by suppressing its processing and degradation. Mol Cell Biol (2006) 26(9):3365-77. doi:10.1128/MCB.26.9.3365-3377.2006

48. Vokes SA, Ji H, McCuine S, Tenzen T, Giles S, Zhong S, et al. Genomic characterization of Gli-activator targets in sonic hedgehog-mediated neural patterning. Development (2007) 134(10):1977-89. doi:10.1242/dev.001966

49. Ching S, Vilain E. Targeted disruption of Sonic hedgehog in the mouse adrenal leads to adrenocortical hypoplasia. Genesis (2009) 47(9):628-37. doi:10.1002/dvg.20532

50. Sul HS. Minireview: Pref-1: role in adipogenesis and mesenchymal cell fate. Mol Endocrinol (2009) 23(11):1717-25. doi:10.1210/me.2009-0160

51. Halder SK, Takemori H, Hatano O, Nonaka Y, Wada A, Okamoto M. Cloning of a membrane-spanning protein with epidermal growth factor-like repeat motifs from adrenal glomerulosa cells. Endocrinology (1998) 139(7):3316-28. doi:10.1210/endo.139.7.6081

52. Zhang P, Greendorfer JS, Jiao J, Kelpke SC, Thompson JA. Alternatively spliced FGFR-1 isoforms differentially modulate endothelial cell activation of c-YES. Arch Biochem Biophys (2006) 450(1):50-62. doi:10.1016/j.abb.2006.03.017

53. Katoh M. Network of WNT and other regulatory signaling cascades in pluripotent stem cells and cancer stem cells. Curr Pharm Biotechnol (2011) 12(2):160-70. doi:10.2174/138920111794295710

54. Chu Y, Ho WJ, Dunn JC. Basic fibroblast growth factor delivery enhances adrenal cortical cellular regeneration. Tissue Eng Part A (2009) 15(8):2093-101. doi:10.1089/ten.tea.2008.0305

55. Crickard K, Ill CR, Jaffe RB. Control of proliferation of human fetal adrenal cells in vitro. J Clin Endocrinol Metab (1981) 53(4):790-6. doi:10.1210/jcem53-4-790

56. Gospodarowicz D, Ill CR, Hornsby PJ, Gill GN. Control of bovine adrenal cortical cell proliferation by fibroblast growth factor. Lack of effect of epidermal growth factor. Endocrinology (1977) 100(4):1080-9. doi:10.1210/endo-100-41080

57. Lepique AP, Moraes MS, Rocha KM, Eichler CB, Hajj GN, Schwindt TT, et al. c-Myc protein is stabilized by fibroblast growth factor 2 and destabilized by ACTH to control cell cycle in mouse Y1 adrenocortical cells. J Mol Endocrinol (2004) 33(3):623-38. doi:10.1677/jme.1.01485

58. Basile DP, Holzwarth MA. Basic fibroblast growth factor receptor in the rat adrenal cortex: effects of suramin and unilateral adrenalectomy on receptor numbers. Endocrinology (1994) 134(6):2482-9. doi:10.1210/en.134.6.2482

59. Revest JM, Spencer-Dene B, Kerr K, De Moerlooze L, Rosewell I, Dickson C. Fibroblast growth factor receptor 2-IIIb acts upstream of Shh and Fgf4 and is required for limb bud maintenance but not for the induction of Fgf8, Fgf10, Msx1, or Bmp4. Dev Biol (2001) 231(1):47-62. doi:10.1006/dbio.2000.0144

60. Kim Y, Bingham N, Sekido R, Parker KL, Lovell-Badge R, Capel B. Fibroblast growth factor receptor 2 regulates proliferation and Sertoli differentiation during male sex determination. Proc Natl Acad Sci U S A (2007) 104(42):16558-63. doi:10.1073/pnas.0702581104
61. Kim AC, Reuter AL, Zubair M, Else T, Serecky K, Bingham NC, et al. Targeted disruption of beta-catenin in Sf1-expressing cells impairs development and maintenance of the adrenal cortex. Development (2008) 135(15):2593-602. doi:10.1242/dev.021493

62. Berthon A, Martinez A, Bertherat J, Val P. Wnt/beta-catenin signalling in adrenal physiology and tumour development. Mol Cell Endocrinol (2012) 351(1):87-95. doi:10.1016/j.mce.2011.09.009

63. Christofer Juhlin C, Goh G, Healy JM, Fonseca AL, Scholl UI, Stenman A, et al. Whole-exome sequencing characterizes the landscape of somatic mutations and copy number alterations in adrenocortical carcinoma. J Clin Endocrinol Metab (2014) 9:jc20143282. doi:10.1210/jc.2014-3282

64. Benhamouche S, Decaens T, Godard C, Chambrey R, Rickman DS, Moinard C, et al. Apc tumor suppressor gene is the "zonation-keeper" of mouse liver. Dev Cell (2006) 10(6):759-70. doi:10.1016/j.devcel.2006.03.015

65. Drelon C, Berthon A, Ragazzon B, Tissier F, Bandiera R, Sahut-Barnola I, et al. Analysis of the role of Igf2 in adrenal tumour development in transgenic mouse models. PLoS One (2012) 7(8):e44171. doi:10.1371/journal.pone. 0044171

66. Berthon A, Drelon C, Ragazzon B, Boulkroun S, Tissier F, Amar L, et al. WNT/beta-catenin signalling is activated in aldosterone-producing adenomas and controls aldosterone production. Hum Mol Genet (2014) 23(4):889-905. doi: $10.1093 / \mathrm{hmg} / \mathrm{ddt} 484$

67. Drelon C, Berthon A, Mathieu M, Martinez A, Val P. Adrenal cortex tissue homeostasis and zonation: a WNT perspective. Mol Cell Endocrinol (2015). doi:10.1016/j.mce.2014.12.014

68. Walczak EM, Kuick R, Finco I, Bohin N, Hrycaj SM, Wellik DM, et al. Wnt signaling inhibits adrenal steroidogenesis by cell-autonomous and non-cellautonomous mechanisms. Mol Endocrinol (2014) 28(9):1471-86. doi:10.1210/ me.2014-1060

69. Heikkila M, Peltoketo H, Leppaluoto J, Ilves M, Vuolteenaho O, Vainio S. Wnt-4 deficiency alters mouse adrenal cortex function, reducing aldosterone production. Endocrinology (2002) 143(11):4358-65. doi:10.1210/en.2002220275

70. Suwa T, Chen M, Hawks CL, Hornsby PJ. Zonal expression of dickkopf-3 and components of the Wnt signalling pathways in the human adrenal cortex. $J$ Endocrinol (2003) 178(1):149-58. doi:10.1677/joe.0.1780149

71. Röhrig T, Pihlajoki M, Ziegler R, Cochran RS, Schrade A, Schillebeeckx $\mathrm{M}$, et al. Toying with fate: redirecting the differentiation of adrenocortical progenitor cells into gonadal-like tissue. Mol Cell Endocrinol (2015). doi:10.1016/j.mce.2014.12.003

72. Hsu SY, Liang SG, Hsueh AJ. Characterization of two LGR genes homologous to gonadotropin and thyrotropin receptors with extracellular leucine-rich repeats and a $G$ protein-coupled, seven-transmembrane region. Mol Endocrinol (1998) 12(12):1830-45. doi:10.1210/mend.12.12.0211

73. Assié G, Letouze E, Fassnacht M, Jouinot A, Luscap W, Barreau O, et al. Integrated genomic characterization of adrenocortical carcinoma. Nat Genet (2014) 46(6):6. doi:10.1038/ng.2953

74. Bernichtein S, Petretto E, Jamieson S, Goel A, Aitman TJ, Mangion JM, et al. Adrenal gland tumorigenesis after gonadectomy in mice is a complex genetic trait driven by epistatic loci. Endocrinology (2007) 149(2):651-61. doi:10.1210/en.2007-0925

75. El Wakil A, Bandulik S, Guy N, Bendahhou S, Zennaro MC, Niehrs C, et al. Dkk3 is a component of the genetic circuitry regulating aldosterone biosynthesis in the adrenal cortex. Hum Mol Genet (2012) 21(22):4922-9. doi: $10.1093 / \mathrm{hmg} / \mathrm{dds} 333$

76. Fottner C, Hoeflich A, Wolf E, Weber MM. Role of the insulin-like growth factor system in adrenocortical growth control and carcinogenesis. Horm Metab Res (2004) 36(6):397-405. doi:10.1055/s-2004-814563

77. Drelon C, Berthon A, Val P. Adrenocortical cancer and IGF2: is the game over or our experimental models limited? J Clin Endocrinol Metab (2013) 98(2):505-7. doi:10.1210/jc.2012-3310

78. Belgorosky A, Baquedano MS, Guercio G, Rivarola MA. Expression of the IGF and the aromatase/estrogen receptor systems in human adrenal tissues from early infancy to late puberty: implications for the development of adrenarche. Rev Endocr Metab Disord (2009) 10(1):51-61. doi:10.1007/s11154-0089105-1

79. Pitetti JL, Calvel P, Romero Y, Conne B, Truong V, Papaioannou MD, et al. Insulin and IGF1 receptors are essential for XX and XY gonadal differentiation and adrenal development in mice. PLoS Genet (2013) 9(1):e1003160. doi:10. 1371/journal.pgen. 1003160 
80. Penhoat A, Rainey WE, Viard I, Saez JM. Regulation of adrenal celldifferentiated functions by growth factors. Horm Res (1994) 42(1-2):39-43. doi:10.1159/000184143

81. Itoh F, Watabe T, Miyazono K. Roles of TGF-beta family signals in the fate determination of pluripotent stem cells. Semin Cell Dev Biol (2014) 32:98-106. doi:10.1016/j.semcdb.2014.05.017

82. Kumar TR, Donehower LA, Bradley A, Matzuk MM. Transgenic mouse models for tumour-suppressor genes. J Intern Med (1995) 238(3):233-8. doi:10.1111/j.1365-2796.1995.tb00928.x

83. Vanttinen T, Liu J, Kuulasmaa T, Kivinen P, Voutilainen R. Expression of activin/inhibin signaling components in the human adrenal gland and the effects of activins and inhibins on adrenocortical steroidogenesis and apoptosis. J Endocrinol (2003) 178(3):479-89. doi:10.1677/joe.0.1780479

84. Looyenga BD, Hammer GD. Genetic removal of Smad3 from inhibin-null mice attenuates tumor progression by uncoupling extracellular mitogenic signals from the cell cycle machinery. Mol Endocrinol (2007) 21(10):18. doi:10.1210/me.2006-0402

85. Looyenga BD, Wiater E, Vale W, Hammer GD. Inhibin-A antagonizes TGFbeta2 signaling by down-regulating cell surface expression of the TGFbeta coreceptor betaglycan. Mol Endocrinol (2010) 24(3):608-20. doi:10.1210/me. 2008-0374

86. Schillebeeckx M, Pihlajoki M, Gretzinger E, Yang W, Thol F, Hiller T, et al. Novel markers of gonadectomy-induced adrenocortical neoplasia. Mol Cell Endocrinol (2015) 399:122-30. doi:10.1016/j.mce.2014.09.029

87. Baba T, Otake H, Sato T, Miyabayashi K, Shishido Y, Wang CY, et al. Glycolytic genes are targets of the nuclear receptor Ad4BP/SF-1. Nat Commun (2014) 5:3634. doi:10.1038/ncomms4634

88. Ruggiero C, Doghman M, Lalli E. How genomic studies have improved our understanding of the mechanisms of transcriptional regulation by NR5A nuclear receptors. Mol Cell Endocrinol (2015). doi:10.1016/j.mce.2014. 10.022

89. Urs AN, Dammer E, Kelly S, Wang E, Merrill AH Jr, Sewer MB. Steroidogenic factor-1 is a sphingolipid binding protein. Mol Cell Endocrinol (2007) 265-266:174-8. doi:10.1016/j.mce.2006.12.016

90. Blind RD, Suzawa M, Ingraham HA. Direct modification and activation of a nuclear receptor-PIP2 complex by the inositol lipid kinase IPMK. Sci Signal (2012) 5(229):ra44. doi:10.1126/scisignal.2003111

91. Parker KL. The roles of steroidogenic factor 1 in endocrine development and function. Mol Cell Endocrinol (1998) 145(1-2):15-20. doi:10.1016/S03037207(98)00164-6

92. Lichtenauer UD, Duchniewicz M, Kolanczyk M, Hoeflich A, Hahner S, Else T, et al. Pre-B-cell transcription factor 1 and steroidogenic factor 1 synergistically regulate adrenocortical growth and steroidogenesis. Endocrinology (2007) 148(2):693-704. doi:10.1210/en.2006-0681

93. Beuschlein F, Mutch C, Bavers DL, Ulrich-Lai YM, Engeland WC, Keegan C, et al. Steroidogenic factor-1 is essential for compensatory adrenal growth following unilateral adrenalectomy. Endocrinology (2002) 143(8):3122-35. doi:10.1210/endo.143.8.8944

94. Figueiredo BC, Cavalli LR, Pianovski MA, Lalli E, Sandrini R, Ribeiro RC, et al. Amplification of the steroidogenic factor 1 gene in childhood adrenocortical tumors. JClin Endocrinol Metab (2005) 90(2):615-9. doi:10.1210/jc.2004-0942

95. Doghman M, Karpova T, Rodrigues GA, Arhatte M, De MJ, Cavalli LR, et al. Increased steroidogenic factor-1 dosage triggers adrenocortical cell proliferation and cancer. Mol Endocrinol (2007) 21(12):2968-87. doi:10.1210/me.20070120

96. Latre de Late P, Wakil AE, Jarjat M, de Krijger RR, Heckert LL, Naquet P, et al. Vanin-1 inactivation antagonizes the development of adrenocortical neoplasia in Sf-1 transgenic mice. Endocrinology (2014) 155(7):16. doi:10.1210/en.20141088

97. Lee FY, Faivre EJ, Suzawa M, Lontok E, Ebert D, Cai F, et al. Eliminating SF-1 (NR5A1) sumoylation in vivo results in ectopic hedgehog signaling and disruption of endocrine development. Dev Cell (2011) 21(2):315-27. doi:10.1016/j.devcel.2011.06.028

98. Lalli E, Melner MH, Stocco DM, Sassone-Corsi P. DAX-1 blocks steroid production at multiple levels. Endocrinology (1998) 139(10):4237-43. doi:10.1210/en. 139.10.4237

99. Achermann JC, Meeks JJ, Jameson JL. Phenotypic spectrum of mutations in DAX-1 and SF-1. Mol Cell Endocrinol (2001) 185(1-2):17-25. doi:10.1016/ S0303-7207(01)00619-0
100. Scheys JO, Heaton JH, Hammer GD. Evidence of adrenal failure in aging Dax1-deficient mice. Endocrinology (2011) 152(9):3430-9. doi:10.1210/en. 2010-0986

101. Zazopoulos E, Lalli E, Stocco DM, Sassone-Corsi P. DNA binding and transcriptional repression by DAX-1 blocks steroidogenesis. Nature (1997) 390(6657):311-5. doi:10.1038/36899

102. Cui S, Ross A, Stallings N, Parker KL, Capel B, Quaggin SE. Disrupted gonadogenesis and male-to-female sex reversal in Pod1 knockout mice. Development (2004) 131(16):4095-105. doi:10.1242/dev.01266

103. Kim AC, Hammer GD. Adrenocortical cells with stem/progenitor cell properties: recent advances. Mol Cell Endocrinol (2007) 26(5-266):10-6. doi:10.1016/ j.mce.2006.12.028

104. Bandiera R, Sacco S, Vidal VP, Chaboissier MC, Schedl A. Steroidogenic organ development and homeostasis: a WT1-centric view. Mol Cell Endocrinol (2015). doi:10.1016/j.mce.2015.01.009

105. Kiiveri S, Liu J, Westerholm-Ormio M, Narita N, Wilson DB, Voutilainen $\mathrm{R}$, et al. Differential expression of GATA-4 and GATA-6 in fetal and adult mouse and human adrenal tissue. Endocrinology (2002) 143(8):3136-43. doi:10.1210/endo.143.8.8939

106. Pihlajoki M, Gretzinger E, Cochran R, Kyrönlahti A, Schrade A, Hiller T, et al. Conditional mutagenesis of Gata6 in SF1-positive cells causes gonadallike differentiation in the adrenal cortex of mice. Endocrinology (2013) 154(5):1754-67. doi:10.1210/en.2012-1892

107. Padua MB, Jiang T, Morse DA, Fox SC, Hatch HM, Tevosian SG. Combined loss of the GATA4 and GATA6 transcription factors in male mice disrupts testicular development and confers adrenal-like function in the testes. Endocrinology (2015). doi:10.1210/en.2014-1907

108. Zhang Y, Goss AM, Cohen ED, Kadzik R, Lepore JJ, Muthukumaraswamy K, et al. A Gata6-Wnt pathway required for epithelial stem cell development and airway regeneration. Nat Genet (2008) 40(7):862-70. doi:10.1038/ng.157

109. Tian Y, Zhang Y, Hurd L, Hannenhalli S, Liu F, Lu MM, et al. Regulation of lung endoderm progenitor cell behavior by miR302/367. Development (2011) 138(7):1235-45. doi:10.1242/dev.061762

110. Beuling E, Baffour-Awuah NY, Stapleton KA, Aronson BE, Noah TK, Shroyer NF, et al. GATA factors regulate proliferation, differentiation, and gene expression in small intestine of mature mice. Gastroenterology (2011) 140(4):e1-2. doi:10.1053/j.gastro.2011.01.033

111. Beuling E, Aronson BE, Tran LM, Stapleton KA, Ter Horst EN, Vissers LA, et al. GATA6 is required for proliferation, migration, secretory cell maturation, and gene expression in the mature mouse colon. Mol Cell Biol (2012) 32(17):3392-402. doi:10.1128/MCB.00070-12

112. Whissell G, Montagni E, Martinelli P, Hernando-Momblona X, Sevillano M, Jung P, et al. The transcription factor GATA6 enables self-renewal of colon adenoma stem cells by repressing BMP gene expression. Nat Cell Biol (2014) 16(7):695-707. doi:10.1038/ncb2992

113. Tsuji S, Kawasaki Y, Furukawa S, Taniue K, Hayashi T, Okuno M, et al. The miR-363-GATA6-Lgr5 pathway is critical for colorectal tumourigenesis. Nat Commun (2014) 5:3150. doi:10.1038/ncomms4150

114. Lancaster MA, Knoblich JA. Organogenesis in a dish: modeling development and disease using organoid technologies. Science (2014) 345(6194):1247125. doi:10.1126/science. 1247125

Conflict of Interest Statement: The authors declare that the research was conducted in the absence of any commercial or financial relationships that could be construed as a potential conflict of interest.

Received: 18 December 2014; accepted: 16 February 2015; published online: 05 March 2015.

Citation: Pihlajoki M, Dörner J, Cochran RS, Heikinheimo $M$ and Wilson DB (2015) Adrenocortical zonation, renewal, and remodeling. Front. Endocrinol. 6:27. doi: 10.3389/fendo.2015.00027

This article was submitted to Cellular Endocrinology, a section of the journal Frontiers in Endocrinology.

Copyright (C) 2015 Pihlajoki, Dörner, Cochran, Heikinheimo and Wilson. This is an open-access article distributed under the terms of the Creative Commons Attribution License (CC BY). The use, distribution or reproduction in other forums is permitted, provided the original author(s) or licensor are credited and that the original publication in this journal is cited, in accordance with accepted academic practice. No use, distribution or reproduction is permitted which does not comply with these terms. 